\title{
PRINCIPIOS INTERNACIONALES QUE CONSAGRAN EL DERECHO HUMANO DE ACCESO A UNA JUSTICIA INDEPENDIENTE. ANÁLISIS DEL TEMA EN ARGENTINA
}

\author{
International Principles that provides the Human Right of Access to an \\ Independent Justice. \\ Analysis concerning this theme in Argentina.
}

Carlos Gonzalo F. Fuentes*

\begin{abstract}
Resumen: Las cuestiones referidas a la independencia judicial en el ámbito del Derecho Internacional y su incidencia en las instituciones domésticas, con especial detenimiento en el caso Argentino, serán reflejadas en el presente trabajo. Para ello efectuamos un análisis e interpretación de diversos instrumentos internacionales y recomendaciones de organismos de Derechos Humanos. Nos proponemos demostrar que el derecho humano que garantiza el acceso a un Poder Judicial independiente, se convierte en el punto de inicio en la faz del reconocimiento efectivo de los derechos y para el cumplimiento de las más altas misiones del estado de derecho.
\end{abstract}

Palabras clave: independencia, judicial, derechos humanos, control, convencionalidad.

Abstract: The questions referred to the Judicial Independence in the field of international law and its impact on domestic institutions, with particular depth in the Argentine case, will be reflected in this work. To do this we make an analysis and interpretation of various international instruments and recommendations of Human Rights Organizations. We intend to demonstrate that the human right that guarantees access to an independent judiciary, becomes the starting point on the face of the effective recognition of the rights and fulfillment of the highest missions the rule of law.

Keywords: independence, judiciary, human rights, control, conventionality.

\section{Introducción}

En el presente trabajo nos proponemos reseñar de manera analítica y sistematizada, los principios emergentes del derecho internacional que constituyen

\footnotetext{
* Abogado, profesor de la asignatura Derecho Público Provincial y Municipal de la Facultad de Ciencias Jurídicas y Sociales de la Universidad Nacional de La Plata. Investigador del Consejo Nacional de Investigaciones Científicas y Técnicas de Argentina (CONICET). Miembro de la Comisión Asesora de Investigación Científica de la Facultad de Ciencias Jurídicas y Sociales de la Universidad Nacional de La Plata. Abogado patrocinante en el caso "Uriarte Rodolfo Marcelo y otro c/Consejo de la Magistratura de la Nación s/acción mere declarativa de incontitucionalidad”. Correo electrónico: carlosgonzalofuentes@gmail.com
}

Este artículo fue recibido el 15 de agosto de 2016, siendo aprobada su publicación el 20 de diciembre de 2016. 
Fuentes - Principios internacionales que consagran el derecho humano de acceso a una justicia...

a la independencia judicial como sustrato irreemplazable del estado de derecho y de la premisa emergente de separación de poderes.

Para el desarrollo del tópico propuesto, ahondaremos en la telesis del Poder Judicial y su importancia para el reconocimiento de derechos en el marco de las instituciones locales y su progresividad en el marco de la internacionalización de derechos.

La metodología utilizada implica el desarrollo de lo que denominamos "principios internacionales sobre los se construye la independencia judicial como derecho humano" tomados de diversos instrumentos internacionales, trabajos e informes de organismos de Derechos Humanos a nivel internacional; de las opiniones consultivas y sentencias de la Corte Interamericana de Derechos Humanos (en adelante Corte IDH), como de las opiniones consultivas y trabajos específicos de la Comisión Interamericana de Derechos Humanos (en adelante CIDH).

Como parte final del presente desarrollo intentaremos reflejar como los principios internacionales sobre los que se sustenta la independencia del Poder Judicial han sido soslayados en la República Argentina en la última década y la destacada labor de la Corte Suprema de la Justicia de ese país (en adelante CSJN) que ha recogido aquellos principios internacionales sincronizándolos a las instituciones domésticas, adecuando estas al estándar convencional de derecho.

En este segmento introductorio aclararé que cuando utilizamos el concepto "control de convencionalidad" nos referimos a una reiterada ponderación por parte de la Corte IDH, en cuanto ha sostenido que ese tribunal ejercita lo que ha dado en llamar, a partir del caso "Myrna Mack Chang" el "control de convencionalidad" que obviamente significa una comparación entre el Pacto de San José de Costa Rica (Convención Americana de Derechos Humanos) y otras convenciones sobre derechos humanos a las que los diversos Estados con jurisdicción en la misma se han plegado; con las disposiciones del derecho interno de las naciones adheridas al modelo.

Cuando se utiliza la terminología de "control de convencionalidad" no se quiere decir que solo a partir de los referidos asuntos la Corte IDH haya ejercido tal potestad, porque desde siempre ha venido haciendo una compulsa entre ambos esquemas, destacando la prioridad de la regla supranacional, lo que en verdad ha sucedido es que desde entonces se utiliza tal fraseología (Hiiters, 2015).

De lo expuesto se colige que el cometido primario de la Corte IDH es efectuar una revisión de convencionalidad "comparando" si los Estados cumplen

\footnotetext{
${ }^{1}$ Corte Interamericana de Derechos Humanos caso "Myrna Mack Chang vs. Guatemala" (2003): Sentencia de 25 de noviembre de 2003, Serie C No. 101. Voto Concurrente Razonado del Juez Sergio García Ramírez. Aquí el citado Juez fue quien utilizó esta terminología.
} 
con la Convención Americana de Derechos Humanos y otros Tratados y desentrañar si hubo quebrantamiento de esas reglas internacionales.

En ese sentido, la sentencia pronunciada por la Corte IDH en el caso "Almonacid Arellano y otros vs. Gobierno de Chile" definió, dentro del marco de vigencia de la Convención Americana sobre derechos humanos, o Pacto de San José de Costa Rica, el "control de convencionalidad", al considerar que: "La Corte es consciente que los jueces y tribunales internos están sujetos al imperio de la ley y, por ello, están obligados a aplicar las disposiciones vigentes en el ordenamiento jurídico. Pero cuando un Estado ha ratificado un tratado internacional como la Convención Americana, sus jueces, como parte del aparato del Estado, también están sometidos a ella, lo que obliga a velar porque los efectos de las disposiciones de la Convención no se vean mermadas por la aplicación de leyes contrarias a su objeto y fin, y que desde un inicio carecen de efectos jurídicos. En otras palabras, el Poder Judicial debe ejercer una especie de "control de convencionalidad" entre las normas jurídicas internas que aplican en los casos concretos y la Convención Americana sobre Derechos Humanos. En esa tarea, el Poder Judicial debe tener en cuenta no solamente el tratado, sino también la interpretación que del mismo ha hecho la Corte Interamericana, intérprete última de la Convención Americana", agregando complementariamente que: "En esa misma línea de ideas, esta Corte ha establecido que '(s)egún el derecho internacional las obligaciones que éste impone deben ser cumplidas de buena fe y no puede invocarse para su incumplimiento el derecho interno'. Esta regla ha sido codificada en el artículo 27 de la Convención de Viena sobre el Derecho de los Tratados, de 1969".

En el caso "Trabajadores Cesados del Congreso (Aguado Alfaro y otros) vs. Perú" la la Corte IDH formuló algunas especificaciones y adiciones al sostener "[c]uando un Estado ha ratificado un tratado internacional como la Convención Americana, sus jueces están sometidos a ella, lo que les obliga a velar porque el efecto útil de la convención no se vea mermado o anulado por la aplicación de leyes contrarias a sus disposiciones, objeto y fin. En otras palabras, los órganos del Poder Judicial deben ejercer no solo un control de constitucionalidad, sino también de convencionalidad, ex officio, entre las normas internas y la convención americana, evidentemente en el marco de sus respectivas competencias y de las regulaciones procesales pertinentes. Esta función no debe quedar limitada exclusivamente por las manifestaciones o actos de los accionantes en cada caso concreto, aunque tampoco implica que ese control deba ejercerse siempre, sin

\footnotetext{
2 Corte Interamericana de Derechos Humanos caso "Almonacid Arellano y otros vs. Chile" (2006): Sentencia de 26 de septiembre de 2006, Excepciones Preliminares, Fondo, Reparaciones y Costas, párrafos 124-125. Esta doctrina fue repetida, sin mayores variantes, en los casos "La Cantuta vs. Perú" (2006): sentencia del 29 de noviembre de 2006, párrafo 173 y "Boyce y otros vs. Barbados" (2007): sentencia del 20 de noviembre de 2007, párrafo78.

3 Corte Interamericana de Derechos Humanos caso "Trabajadores Cesados del Congreso (Aguado Alfaro y otros) vs. Perú" (2006): Sentencia de 24 de noviembre de 2006, Excepciones Preliminares, Fondo, Reparaciones y Costas, párrafo 128. Más recientemente se volvió a ratificar esta doctrina en el caso "Raxcacó Reyes vs. Guatemala" (2008): sentencia del 9 de mayo de 2008, párrafo 63.
} 
Fuentes - Principios internacionales que consagran el derecho humano de acceso a una justicia...

considerar otros supuestos formales y materiales de admisibilidad y procedencia de este tipo de acciones".

En ese orden, resulta importante aclarar que la inspección de convencionalidad debe ser llevada a cabo primero en el campo doméstico en cuyo caso será un "control primario", lo que implica un cotejo entre las normas internacionales y las domésticas.

Como coralario del presente ítem concluimos en afirmar que la figura del control de convencionalidad, es una verdadera manifestación del control de constitucionalidad del Derecho Internacional, que implica un nuevo paradigma para el Estado constitucional latinoamericano (Hiiters, 2015).

\section{Telesis del Poder Judicial. Su incidencia en el reconocimiento de derechos}

El judicial es considerado un poder contramayoritario por tener la misión republicana de controlar los excesos de los poderes políticos, de allí surge su preponderante e ineludible perfil técnico.

En sus orígenes, el otorgamiento a este poder del control de constitucionalidad surgió frente a la sospecha o desconfianza que pesaba sobre las mayorías asamblearias de ocasión y tendió a evitar que los poderes constituidos desconozcan la supremacía de la soberanía del pueblo y del poder constituyente. ${ }^{4}$

Un poder judicial independiente e imparcial constituye una garantía mediante la cual los derechos y libertades individuales se encuentren a resguardo

\footnotetext{
${ }^{4}$ Hamilton, Madison y Jay (1957): “...Quien considere con atención los distintos departamentos del poder, percibirá que en un gobierno en que se encuentren separados, el judicial, debido a la naturaleza de sus funciones, será siempre el menos peligroso para los derechos políticos de la Constitución, porque su situación le permitirá estorbarlos o perjudicarlos en menor grado que los otros poderes. El Ejecutivo no sólo dispensa los honores, sino que posee la fuerza militar de la comunidad. El legislativo no sólo dispone de la bolsa, sino que dicta las reglas que han de regular los derechos y los deberes de todos los ciudadanos. El judicial, en cambio, no influye ni sobre las armas, ni sobre el tesoro; no dirige la riqueza ni la fuerza de la sociedad, y no puede tomar ninguna resolución activa. Puede decirse con verdad que no posee fuerza ni voluntad, sino únicamente discernimiento, y que ha de apoyarse en definitiva en la ayuda del brazo ejecutivo hasta para que tengan eficacia sus fallos". Estas ideas reflejadas en El Federalista, que con tanto énfasis describen la misión del poder judicial, fueron tomadas de la clásica obra El Espíritu de las Leyes de Montesquieu, donde se afirma que "...Cuando el poder legislativo y el ejecutivo se reúnen en la misma persona o el mismo cuerpo de magistrados, no hay libertad... No hay tampoco libertad si el poder judicial no está separado del legislativo y el ejecutivo. Si está unido a la potestad legislativa, el poder de decidir de la vida y la libertad de los ciudadanos será arbitrario, porque el juez será al mismo tiempo legislador: si está unido al poder ejecutivo, el juez tendrá en su mano la fuerza de un opresor. Todo estaría perdido si el mismo hombre... ejerciese estos tres poderes: el de hacer las leyes, el de ejecutar las resoluciones públicas y el de juzgar los delitos o las diferencias de los particulares".
} 
de cualquier menoscabo. La independencia de los tribunales de justicia es de vital importancia para evitar los desbordes de poder y surge como un contrapeso natural asociado a la evolución misma del constitucionalismo en su faz moderna y como dato de consolidación de la democracia liberal.

Para ejercer en plenitud su cometido esencial, el judicial debe contar con la atribución expresa de declarar nulos todos los actos contrarios al sentido evidente de la constitución, de la cual emergen las prerrogativas de los otros poderes del estado. El fin inmediato que persigue esta atribución conferida al Poder Judicial, constituye la salvaguarda para que los postulados en favor del reconocimiento de determinados derechos o garantías no se conviertan en meras declamaciones.

Las facultades encomendadas al Poder Judicial de analizar la constitucionalidad y convencionalidad de los actos u omisiones, tanto del legislativo como del Poder Ejecutivo, suscitan aún en la actualidad ciertas dudas en tanto ello implicaría la superioridad del poder judicial frente a aquellos poderes constituidos.

En ese orden de ideas, recogiendo los conceptos utilizados por Hamilton en "El Federalista" (Hamilton, Madison y Jay, 1957) en el sentido que ningún acto legislativo contrario a la constitución puede ser válido, no resulta baladí aclarar que no es razonable suponer que la misma haya podido tener la intención de facultar a los representantes del pueblo para sustituir la voluntad de sus electores, concluyendo que los tribunales han sido concebidos como un cuerpo intermedio entre el pueblo y la legislatura con la finalidad, entre otras varias, de mantener a esta última dentro de los límites asignados a su autoridad.

Esta conclusión no supone de ningún modo la superioridad del Poder Judicial sobre el legislativo tan solo significa, en el entendimiento propuesto, que el poder del pueblo es superior a ambos y que donde la voluntad de la legislatura, plasmada en sus leyes, se halla en oposición con la del pueblo, declarada en la constitución, los jueces deberán gobernarse por la última de preferencia a las primeras.

De tal modo es dable considerar que la función judicial "compensa el déficit democrático de la decisión política actualmente dedicada a la pura gestión y a dar a la sociedad aquel referente simbólico siempre menos identificable en el parlamento"; ella se torna intérprete de los derechos de todos y a veces de las minorías, frecuentemente contra las razones particulares o prevaricadoras de la política oficial y lo hace "desde abajo", esto es, partiendo de los casos, de la pretensión de los interesados (Donini, 2004).

Para el logro de esos cometidos, el estado de derecho debe garantir la separación de poderes y en lo concerniente al Poder Judicial, ello se traduce en la necesaria independencia que debe tener respecto de los poderes políticos, tema sobre el cual haremos hincapié en el presente desarrollo. 
Fuentes - Principios internacionales que consagran el derecho humano de acceso a una justicia...

Más específicamente, la independencia del Poder Judicial siempre se ha entendido como una consecuencia necesaria de la separación de los poderes dirigida a garantizar la resistencia de los jueces frente a las presiones o embates tanto del legislativo como del ejecutivo.

En tal sentido, desde su germen la independencia de los jueces constituyó la base de la separación de los poderes y se concibe como una pieza insustituible del Estado democrático de derecho "que además implica otras exigencias adyacentes, como un sistema procesal regular, ordenado y coherente, así como garante de la seguridad jurídica y de los derechos humanos de las personas" (Díaz, 1998).

Desde el plexo internacional de derecho surge que "la Carta Democrática Interamericana no se limita a reconocer como elementos esenciales de la democracia representativa al respeto de los derechos humanos y las libertades fundamentales, y a elementos propios de la democracia electoral, sino que exige también la separación e independencia de los poderes públicos, entre los que en este caso debe desatacarse la concerniente a la función jurisdiccional. El papel de los jueces en la gobernabilidad democrática de los Estados pasa por reconocerles una genuina separación e independencia del resto, esto es, en definitiva, del poder político, no solo en el aspecto personal, que corresponde a cada uno de los miembros de la judicatura, sino en su aspecto institucional, en cuanto cuerpo de autoridad separado en el concierto de las que componen el Estado". 5

Sobre el particular, la Asamblea General de las Naciones Unidas ha manifestado en varias oportunidades que "el imperio del derecho y la adecuada administración de justicia cumplen un papel central en la promoción y protección de los derechos humanos" y que "la administración de justicia, incluidos los organismos encargados de hacer cumplir la ley y del enjuiciamiento y, en particular, un poder judicial independiente, en plena conformidad con las normas contenidas en los instrumentos internacionales de derechos humanos, son esenciales para la plena realización de los derechos humanos sin discriminación alguna y resultan indispensables para los procesos de democratización y el desarrollo sostenible".

De lo expuesto, concluimos que las cuestiones referentes al afianzamiento de la justicia como dato sustancial de la vida republicana, es motivo de especial preocupación en la génesis del postulado teórico de la división de poderes y sobre la base de dicho principio se proyectó la pervivencia de la constitución escrita como norma jerárquica superior; y en la actualidad, su incidencia se proyecta hacia la efectiva vigencia y reconocimiento de los derechos humanos. Actualmente el

\footnotetext{
${ }^{5}$ Corte Interamericana de derechos Humanos caso "Corte Suprema de Justicia (Quintana Coello y otros) vs. Ecuador” (2013): 23 de agosto de 2013, del voto concurrente del Juez Eduardo Ferrer Mac-Gregor Poisot a la sentencia, párrafo 7.

${ }^{6}$ Resoluciones 48/137 de 20 diciembre de 1993 y 50/181 de 22 de diciembre de 1995, tituladas

"Los derechos humanos en la administración de justicia".
} 
desarrollo evolutivo afincado en la internacionalización del derecho, nos lleva a que debamos referirnos al Estado Convencional de Derecho, de donde surgen los principios que engrosan su afianzamiento y vigencia. De ellos partiremos para formular nuestra propuesta metodológica.

\section{El acceso a la justicia y el debido proceso}

Para comenzar a delinear los contornos que demarcan la Independencia Judicial, vale destacar que la Corte IDH enfatiza el deber positivo para los Estados que se desprende del artículo 1 de la Convención que les obliga no solamente a respetar los derechos y libertades reconocidos en ella, sino a garantizar su libre y pleno ejercicio a toda persona sujeta a su jurisdicción, ${ }^{7}$ lo que hace referencia expresa a la obligación estatal de proveer los mecanismos procesales de tutela de los derechos: "La protección de la ley la constituyen, básicamente, los recursos que ésta dispone para la protección de los derechos garantizados por la Convención, los cuales, a la luz de la obligación positiva que el artículo 1.1 contempla para los Estados de respetarlos y garantizarlos, implica (...) el deber de los Estados partes de organizar todo el aparato gubernamental y, en general, todas las estructuras a través de las cuales se manifiesta el ejercicio del poder público, de manera tal que sean capaces de asegurar jurídicamente el libre y pleno ejercicio de los derechos humanos".

Esta obligación no se ve satisfecha cuando los mecanismos adecuados del Estado no son puestos a funcionar para atender la investigación de la violación de los derechos fundamentales, así también al cumplimiento de deberes como la reparación de los daños causados y la sanción a las personas responsables, contenidos en el artículo 1.1 de la Convención.

En lo que respecta al presente trabajo, conviene destacar que el acceso a la justicia en su compleja extensión es un derecho que se desprende, en los términos del plexo normativo interamericano, de las mandas de los artículos 8 y 25 de la Convención Americana de Derechos Humanos.

Dichos artículos establecen un mandato para los Estados y componen los precedentes inmediatos para la observancia de los mecanismos de protección de los derechos humanos en el derecho interno. Esos mecanismos, tanto judiciales como administrativos, son determinantes para el progresivo afianzamiento de los derechos humanos y a la vez constituyen un pilar para afianzar la justicia constitucional de los Estados.

\footnotetext{
${ }^{7}$ Corte Interamericana de Derechos Humanos, Opinión Consultiva oc-11/90 del 10 de agosto de 1990 "Excepciones al agotamiento de los recursos internos" (arts. 46.1, 46.2.a y 46.2.b, Convención Americana sobre Derechos Humanos), párrafo 34.

${ }^{8}$ Ibid, párrafo 23.
} 
Fuentes - Principios internacionales que consagran el derecho humano de acceso a una justicia...

Los artículos en análisis, además de establecer el derecho de acceso a la justicia, consagran derechos específicos que deben ser respetados en el desarrollo de los procesos judiciales y administrativos.

En dicho entendimiento, la Corte IDH ha definido el debido proceso, señalando que "[e]l respeto a los derechos humanos constituye un límite a la actividad estatal, lo cual vale para todo órgano o funcionario que se encuentre en una situación de poder, en razón de su carácter oficial, respecto de las demás personas. Es, así, ilícita, toda forma de ejercicio del poder público que viole los derechos reconocidos por la Convención. Esto es aún más importante cuando el Estado ejerce su poder sancionatorio, pues éste no sólo presupone la actuación de las autoridades con un total apego al orden jurídico, sino implica además la concesión de las garantías mínimas del debido proceso a todas las personas que se encuentran sujetas a su jurisdicción, bajo las exigencias establecidas en la Convención".

La Corte IDH reafirma que el acceso a la justicia no es un derecho que se refiera privativamente a conocer procesos desarrollados solo ante los tribunales de justicia del Estado, se refiere a todo asunto estatal que puede ser de diverso carácter, no solo judicial sino también administrativo. Así es que la Corte IDH ha señalado que las garantías del debido proceso no solo deben contemplarse a lo largo del desarrollo de los procedimientos judiciales, sino también en las materias de carácter administrativo, en tal sentido afirma que "[d]e acuerdo a lo dispuesto en el Artículo 8.1 de la Convención, en la determinación de los derechos y obligaciones de los personas, de orden penal, civil, laboral, fiscal o de cualquier otro carácter, se deben observar 'las debidas garantías' que aseguren, según el procedimiento que se trate, el derecho al debido proceso". ${ }^{10}$

En aquellos casos en que las personas acceden a tribunales y estos no cumplen con el derecho a un debido proceso, el mismo hecho de administrar justicia constituye en sí mismo una violación a los derechos fundamentales, lo que tiene relación directa con las obligaciones que asumen los jueces como operadores de justicia, siendo que sobre ellos recae el deber de administrar justicia conforme a los estándares del debido proceso.

Es por ello que los jueces tienen el deber de cumplir y hacer cumplir el principio del debido proceso, constituyéndose en garantes de los derechos esgrimidos como pretensiones de los particulares, debiendo garantizar un trato imparcial e igualitario que evite toda situación de indefensión.

\footnotetext{
9 Corte Interamericana de Derechos Humanos caso "Tribunal Constitucional vs. Perú" (2001): sentencia de 31 de enero de 2001, Fondo, Reparaciones y Costas, párrafo 68.

${ }^{10}$ Corte Interamericana de Derechos Humanos caso "Barbani Duarte y Otros vs. Uruguay" (2011): sentencia del 13 de octubre de 2011, Fondo, Reparaciones y Costas, párrafo 117.
} 
El artículo 8 de la Convención Americana -en lo que es de nuestro interés- consagra también el derecho a un juez natural que cumpla con las características de independencia e imparcialidad. Frente a ello, la Corte IDH ha ponderado que el debido proceso "implica la intervención de un órgano judicial independiente imparcial, apto para determinar la legalidad de las actuaciones que se cumplan dentro del Estado de excepción". En efecto afirma que "Toda persona sujeta a un juicio de cualquier naturaleza ante un órgano del Estado deberá contar con la garantía de que dicho órgano sea imparcial y actúe en los términos del procedimiento legalmente previsto para el conocimiento y resolución del caso que se le somete". ${ }^{11}$

En suma, todas las personas tienen derecho de acceder a un juez que cumpla con características esenciales que aseguren un resultado justo al momento de determinar si efectivamente existió una vulneración a los derechos humanos.

En consonancia con el desarrollo del presente acápite, es oportuno señalar que el compromiso internacional previsto en la Convención Americana de Derechos Humanos de garantizar el acceso a la justica, constituye el punto de inicio para el reconocimiento efectivo de los derechos allí postulados. De tal modo, el acceso a la justicia en su faz progresiva, se traduce en el Derecho Humano a gozar de una justicia independiente que respete el estándar trasnacional del debido proceso.

En una reciente sentencia, la Corte IDH sostuvo “...que el derecho a ser juzgado por un juez o tribunal imparcial es una garantía fundamental del debido proceso, debiéndose garantizar que el juez o tribunal en el ejercicio de su función como juzgador cuente con la mayor objetividad para enfrentar el juicio. Este Tribunal ha establecido que la imparcialidad exige que el juez que interviene en una contienda particular se aproxime a los hechos de la causa careciendo, de manera subjetiva, de todo prejuicio y, asimismo, ofreciendo garantías suficientes de índole objetiva que inspiren la confianza necesaria a las partes en el caso, así como a los ciudadanos en una sociedad democrática. La imparcialidad del tribunal implica que sus integrantes no tengan un interés directo, una posición tomada, una preferencia por alguna de las partes y que no se encuentren involucrados en la controversia...". ${ }^{12}$

En tanto, la CIDH considera que las juezas y los jueces son los principales actores para lograr la protección judicial de los derechos humanos en un Estado democrático, así como del debido proceso que debe observarse cuando es el mismo quien puede establecer una sanción. Las juezas y los jueces

\footnotetext{
11 Artículo 8 de la Convención Americana sobre Derechos Humanos. Cfr. Corte Interamericana de Derechos Humanos, caso "Genie Lacayo vs. Nicaragua" (1997): Sentencia de 29 de enero de 1997, Fondo, Reparaciones y Costas, párrafo 74.

${ }^{12}$ Corte Interamericana de Derechos Humanos caso "Duque vs. Colombia" (2016): sentencia de 26 de febrero de 2016, Excepciones Preliminares, Fondo, Reparaciones y Costas, párrafo 162.
} 
Fuentes - Principios internacionales que consagran el derecho humano de acceso a una justicia...

fungen en un sistema democrático como contralores de la convencionalidad, constitucionalidad y legalidad de los actos de otros poderes del Estado y funcionarios del mismo en general, así como impartidores de justicia en relación con las controversias generadas por actos de particulares que puedan afectar los derechos de las personas. ${ }^{13}$

Para que un juicio sea justo, el juez o tribunal de la causa deben ser independientes. Todos los instrumentos internacionales de derechos humanos se refieren a un juicio justo por "un tribunal independiente e imparcial". El Comité de Derechos Humanos de Naciones Unidas, adoptó en repetidas ocasiones la opinión de que el derecho a un tribunal independiente e imparcial es "un derecho absoluto que no admite excepciones". ${ }^{14}$

En síntesis, los Estados en su moderna concepción "convencional de derecho" deben asegurar el acceso a la justicia, pero dicha obligación para ser efectiva en los términos del derecho internacional implica, a su vez, garantizar la independencia del Poder Judicial.

\section{La Independencia Judicial en el Derecho Internacional}

El principio de independencia del Poder Judicial ha sido reconocido como "costumbre internacional y principio general de derecho"15 e incorporado en numerosos tratados internacionales. ${ }^{16}$

Como ya fue expresado en el acápite anterior, la independencia de todo órgano que realice funciones de carácter jurisdicciona ${ }^{17}$ es un presupuesto

\footnotetext{
13 Comisión Interamericana de Derechos Humanos "Informe sobre la situación de derechos humanos en Venequela”, OEA/Ser.L/V/II.118, Doc. 4 rev. 1., 24 de octubre de 2003, párrafo 150.

${ }^{14}$ Comité de Derechos Humanos, Dictamen de 28 de octubre de 1992 (Comunicación 263/1987, caso "Miguel González del Río vs. Perú”, párrafo 5.2.

15 Naciones Unidas. Asamblea General. Consejo de Derechos Humanos. Informe del Relator Especial sobre la independencia de los magistrados y abogados, Leandro Despouy, A/HRC/11/41, 24 de marzo de 2009, párrafo 14.

16 La importancia de un poder judicial independiente ha sido expresamente reconocida en los siguientes instrumentos internacionales y regionales: Declaración Universal de los Derechos Humanos (Artículo 10); Pacto Internacional de Derechos Civiles y Políticos (Artículo 14); Declaración y Programa de Acción de Viena de 1993 (Párrafo 27); Convención Americana sobre Derechos Humanos (Artículo 8.1); Convenio Europeo para la Protección de los Derechos Humanos y de las Libertades Fundamentales (Artículo 6.1) y la Carta Africana sobre los Derechos Humanos y de los Pueblos (Artículo 7.1). Asimismo algunos otros tratados internacionales más específicos que también refieren disposiciones relativas a la independencia e imparcialidad de los tribunales son: Convención Internacional sobre la Protección de los Derechos de todos los Trabajadores Migratorios y de sus Familiares (Artículo 18.1); Convención Internacional para la Protección de todas las Personas contra las Desapariciones Forzadas (Artículo 11.3); Protocolo Adicional a los Convenios de Ginebra (Artículo 75.4) y Protocolo Adicional relativo a la protección de las víctimas de los conflictos armados sin carácter internacional (Protocolo II) (Artículo 6.2).
} 
indispensable para el cumplimiento de las normas del debido proceso en tanto derecho humano y su ausencia afecta el ejercicio del derecho de acceder a la justicia, aparte de generar desconfianza y hasta temor que orille a las personas a no recurrir a la los tribunales. ${ }^{18}$

El Relator Especial sobre la independencia de jueces y abogados ha subrayado que "el principio de la división de poderes es la base de los requisitos de la independencia e imparcialidad del poder judicial. El entendimiento y respeto del principio de la división de poderes es indispensable para un Estado democrático". ${ }^{19}$ Asimismo, señaló que "los requisitos de independencia e imparcialidad de la justicia son universales y se basan tanto en el derecho natural como en el positivo. En el plano internacional las fuentes de este último derecho radican en los compromisos convencionales, las obligaciones consuetudinarias y los principios generales del derecho. (...) Los principios fundamentales de la independencia y la imparcialidad de la justicia (...) son 'principios generales de derecho reconocidos por las naciones civilizadas' en el sentido del inciso c) del párrafo 1 del Artículo 38 del Estatuto de la Corte Internacional de Justicia." ${ }^{20}$

Atendiendo a lo establecido en los Principios Básicos de las Naciones Unidas $^{21}$ sobre la independencia de la judicatura a un nivel institucional, ella debe ser garantizada por el Estado y proclamada por la constitución o la legislación del país y resulta primordial que dicha independencia se garantice jurídicamente al más alto nivel posible, ${ }^{22}$ de tal manera que aunque esté consagrada en la constitución, debe recogerse también en la legislación. ${ }^{23}$

Sobre el punto, la Corte IDH considera que las constituciones y leyes nacionales deben observar dicho principio y el sistema de administración de justicia en su conjunto debe estar organizado de manera tal que la independencia

\footnotetext{
17 Corte Interamericana de Derechos Humanos caso "Tribunal Constitucional vs. Perú" (2001): Sentencia de 31 de enero de 2001. Serie C No. 71, párrafo 71.

18 Asamblea General de las Naciones Unidas, Promoción y Protección de todos los Derechos Humanos, Civiles, Políticos, Económicos, Sociales y Culturales, incluido el Derecho al Desarrollo. Informe del Relator Especial sobre la independencia de los magistrados y abogados, Leandro Despouy, A/HRC/8/4, 13 de mayo de 2008, párrafo 34.

${ }^{19}$ Informe de Relator Especial sobre independencia de jueces y abogados, Documento de la ONU E/ CN.4/1995/39, párrafo 55.

${ }^{20}$ Ibid., párrafos 32 y 34.

${ }^{21}$ Principios Básicos de las Naciones Unidas relativos a la independencia de la judicatura adoptados por el Séptimo Congreso de las Naciones Unidas sobre Prevención del Delito y Tratamiento del Delincuente, celebrado en Milán, Italia, del 26 de agosto al 6 de septiembre de 1985 y confirmados por la Asamblea General en sus resoluciones 40/32 del 29 de noviembre de 1985 y 40/146 del 13 de diciembre de 1985.

${ }^{22}$ Naciones Unidas. Asamblea General. Consejo de Derechos Humanos. Informe del Relator Especial sobre la independencia de los magistrados y abogados, Leandro Despouy, A/HRC/11/41, 24 de marzo de 2009, párrafo 21.

${ }_{23}$ Naciones Unidas. Asamblea General. Consejo de Derechos Humanos. Informe del Relator Especial sobre la independencia de los magistrados y abogados. Ob. cit., párrafo 22.
} 
Fuentes - Principios internacionales que consagran el derecho humano de acceso a una justicia...

del Poder Judicial sea garantizada. ${ }^{24}$ En ese orden, el tribunal interamericano recuerda que según lo ha precisado el Comité de Derechos Humanos de Naciones Unidas "toda situación en que las funciones y competencias del poder judicial y del poder ejecutivo no sean claramente distinguibles o en la que este último pueda controlar o dirigir al primero es incompatible con el concepto de un tribunal independiente". ${ }^{25}$

Los estándares emergentes del derecho internacional, disponen que los Estados están obligados a organizar su Poder Judicial de modo de garantizar y asegurar el goce de los derechos y las libertades protegidos internacionalmente. $\mathrm{Al}$ respecto la Corte IDH ha dicho que "en la protección a los derechos humanos, está necesariamente comprendida la noción de la restricción al ejercicio del poder estatal". ${ }^{26}$

El aparato del Estado debe estar organizado de modo que sea compatible con las obligaciones internacionales asumidas, ya sean tácitas o expresas como fuera referido al desarrollar el acápite de acceso a la justica y debido proceso con cita de la Opinión Consultiva oc-11/90 del 10 de agosto de 1990 de la Corte IDH.

Conforme a la jurisprudencia de la Corte IDH y del Tribunal Europeo de Derechos Humanos, así como de conformidad con los Principios Básicos de las Naciones Unidas relativos a la independencia de la judicatura, las siguientes garantías se derivan de la independencia judicial: i) adecuado proceso de selección y nombramiento de los magistrados; ii) inamovilidad del cargo; y iii) garantías para evitar presiones.

\section{IV.1. Proceso de selección y nombramiento de magistrados}

Un adecuado proceso de nombramiento y selección constituye un presupuesto esencial para garantizar la independencia de las y los operadores de justicia. ${ }^{27}$

\footnotetext{
${ }^{24}$ Corte Interamericana de Derechos Humanos caso "Anzualdo Castro vs. Perú" (2009): Sentencia de 22 de septiembre de 2009. Excepción Preliminar, Fondo, Reparaciones y Costas. Serie C No. 202, párrafo 125.

${ }^{25}$ Naciones Unidas. Comité de Derechos Humanos. Observación General No. 32, CCPR/C/GC/32, 23 de agosto de 2007, párrafo 19.

26 Opinión Consultiva de la Corte Interamericana de Derechos Humanos La expresión "leyes" en el artículo 30 de la Convención Americana sobre Derechos Humanos (1986): 9 de mayo de 1986, 0C-6/86, Serie A No. 6, párrafo 21. También sentencia de la Corte Interamericana de Derechos Humanos caso "Velásquez Rodríguez vs. Honduras" (1988): de 29 de julio de 1988, Serie C No. 4, párrafo 165 y del mismo Tribunal caso "Godínez Cruz vs. Honduras" (1989): sentencia de 20 de enero de 1989, Serie C No. 5, párrafo 174.

${ }^{27}$ La Corte Interamericana de Derechos Humanos respecto de la independencia de las juezas y jueces se ha pronunciado en caso "Palamara Iribarne vs. Chile" (2005): Sentencia de 22 de noviembre de 2005. Fondo, Reparaciones y Costas. Serie C No. 135, párrafo 156; caso "Tribunal Constitucional vs. Perú" (2001): Sentencia de 31 de enero de 2001. Fondo, Reparaciones y Costas. Serie C No. 71, párrafo 75. En igual sentido, caso "Chocrón Chocrón vs. Venezuela" (2011): Sentencia de 1 de julio de 2011. Excepción Preliminar, Fondo, Reparaciones y Costas. Serie C No. 22 7, párrafo 98; caso "Apitz Barbera y otros ("Corte Primera de lo Contencioso Administrativo")
} 
El derecho internacional ha establecido algunos criterios mínimos para que los procedimientos para el nombramiento de las y los operadores de justicia seleccionados reúnan condiciones que se traduzcan en un verdadero régimen independiente que permita el acceso a la justicia.

A este respecto la $\mathrm{CIDH}$ considera que si no se respetan ciertos parámetros básicos, el régimen de selección y nombramiento podría facilitar un alto grado de discrecionalidad por parte de las autoridades que participan en el proceso, en virtud de lo cual las personas escogidas no serían, necesariamente, las más idóneas. ${ }^{28}$

Asimismo, la Corte IDH ha sostenido que todas las leyes que regulen el acceso a la función pública deben garantizar mecanismos óptimos que permitan el acceso igualitario a los cargos en forma efectiva, respetando el principio de igualdad y no discriminación. ${ }^{29}$ Dichos principios deben ser observados por las autoridades encargadas de su aplicación y el Estado debe garantizar las condiciones institucionales y técnicas para su materialización.

En tanto los magistrados deben ser los garantes de la recta aplicación y análisis del plexo jurídico, la selección de los mismos debe hacerse atendiendo criterios objetivos de idoneidad en base a su capacidad profesional y mérito personal. A lo dicho debemos agregar que la Asamblea General de Naciones Unidas ha considerado en cuanto al mérito personal, que se debe elegir personas que sean íntegras, idóneas, que cuenten con la formación o calificaciones jurídicas apropiadas. ${ }^{30}$

Los concursos públicos de oposición y de mérito pueden ser un medio adecuado para la designación de operadores de justicia con base a la cualidad y capacidades profesionales. En tales concursos pueden incluirse aspectos como la formación profesional y los años de experiencia requeridos para el cargo, los resultados derivados de la aplicación de exámenes donde se respete el carácter anónimo de las pruebas, ${ }^{31}$ de tal forma que no sean seleccionados ni nombrados

vs. Venezuela" (2008): Sentencia de 5 de agosto de 2008. Excepción Preliminar, Fondo, Reparaciones y Costas. Serie C No. 182, párrafo 138.

28 Corte Interamericana de Derechos Humanos caso "Reverón Trujillo vs. Venezuela" (2009): Sentencia de 30 de junio de 2009. Excepción Preliminar, Fondo, Reparaciones y Costas. Serie C No. 197, párrafo 74.

${ }^{29}$ Corte Interamericana de Derechos Humanos caso "Yatama vs. Nicaragua" (2005): Sentencia de 23 de junio de 2005. Excepciones Preliminares, Fondo, Reparaciones y Costas. Serie C No. 127, párrafo 195.

${ }^{30}$ Principio 10 de los Principios Básicos relativos a la independencia de la judicatura adoptados por el Séptimo Congreso de las Naciones Unidas sobre Prevención del Delito y Tratamiento del Delincuente, celebrado en Milán del 26 de agosto al 6 de septiembre de 1985 y confirmados por la Asamblea General en sus resoluciones 40/32 del 29 de noviembre de 1985 y 40/146 de 13 de diciembre de 1985. Disponible: http://www2.ohchr.org/spanish/law/judicatura.htm.

31 Naciones Unidas. Consejo Económico y Social. Comisión de Derechos Humanos. Informe presentado por Leandro Despouy, Relator Especial sobre la independencia de los magistrados y abogados. Adición. 
Fuentes - Principios internacionales que consagran el derecho humano de acceso a una justicia...

operadores de justicia de modo discrecional y puedan acceder todas las personas que estén interesadas y reúnan los requisitos.

La CIDH ha estimado que se debe garantizar que sean adecuadamente valorados tanto el mérito personal como la capacidad profesional y en condiciones de igualdad dentro de los procesos de selección y nombramiento, en base a criterios objetivos para determinar con precisión su contenido. Dichos criterios deberían a su vez estar consagrados en instrumentos normativos del Estado a fin de asegurar su observancia y exigibilidad, ${ }^{32}$ conforme con pautas de estimación previamente regladas.

\section{IV.2. Inamovilidad de los magistrados}

Para mantener la necesaria equidistancia de los otros poderes, los jueces deben estar provistos de garantías institucionales a fin de no ser removidos de su cargo por simples decisiones del poder político. Ello implica que, con sustento en las máximas del sistema republicano de gobierno en cuanto al equilibrio de poderes, la función judicial se encuentre resguardada en las constituciones como norma jerárquicamente superior, con la garantía de inamovilidad.

En el desarrollo de postulados internacionales sobre el punto, se ha sostenido que una de las condiciones básicas para que los jueces mantengan su independencia es la seguridad de la permanencia en el cargo. Si no tienen seguridad de permanecer en él durante un tiempo razonable y prolongado los jueces son susceptibles a presiones de diferentes sectores, principalmente de quienes depende la renovación de sus cargos.

Este problema se presenta con especial gravedad en países donde el Poder Ejecutivo desempeña una función predominante en la selección y designación de los jueces. En dichos países los jueces pueden ser sometidos y verse forzados a ceder ante presiones políticas para lograr la renovación de sus cargos, lo cual compromete su independencia. ${ }^{33}$

En cuanto a este tópico la Corte IDH ha señalado que el alcance de las garantías judiciales y de la protección judicial efectiva para los jueces, debe ser analizado en relación con los estándares sobre independencia judicial. En el caso

\footnotetext{
Misión a Brasil. E/CN.4/2005/60/Add.3, 22 de febrero de 2005, párrafo 58. Respecto de este punto, ver Corte Europea de Derechos Humanos case "Galstyan vs. Armenia" (2007): 15 Noviembre 2007, párrafo 62, donde la Corte Europea se ha referido a la práctica de pruebas especiales de competencia a candidatos y candidatas como una garantía de su independencia.

32 Comisión Interamericana de Derechos Humanos "Garantías para la independencia de las y los operadores de justicia. Hacia el fortalecimiento del acceso a la justicia y el estado de derecho en las américas” (2013): párrafo 78. Disponible en http://www.cidh.org

33 Comisión Internacional de Juristas (2007): Principios Internacionales sobre Independencia y Responsabilidad de Jueces, Abogados y Fiscales. Guía para profesionales $\left(\mathrm{N}^{\circ}\right.$ 1), Editorial Comisión Internacional de Juristas, Ginebra, pp. 53.
} 
"Reverón Trujillo vs. Venezuela" la Corte precisó que los jueces, a diferencia de los demás funcionarios públicos, cuentan con garantías específicas debido a la independencia necesaria del Poder Judicial, lo que ha sido entendido por la Corte como "esencial para el ejercicio de la función judicial". ${ }^{34}$ El Tribunal reiteró que uno de los objetivos principales que tiene la separación de los poderes públicos es la garantía de la independencia de los jueces. ${ }^{35}$

El objetivo de la protección radica en evitar que el sistema judicial en general y sus integrantes en particular se vean sometidos a posibles restricciones indebidas en el ejercicio de su función por parte de órganos ajenos al Poder Judicial o, incluso, por parte de aquellos magistrados que ejercen funciones de revisión o apelación. ${ }^{36}$

La Corte IDH ha sostenido reiteradamente ${ }^{37}$ que entre los elementos de la inamovilidad, los Principios Básicos establecen que "la ley garantizará la permanencia en el cargo de los jueces por los períodos establecidos" garantizará la inamovilidad de los jueces, tanto de los nombrados mediante decisión administrativa como de los elegidos, hasta que cumplan la edad para la jubilación forzosa o expire el período para el que hayan sido nombrados o elegidos, cuando existan normas al respecto". ${ }^{39}$

Además, el Comité de Derechos Humanos ha señalado que los jueces solo pueden ser removidos por faltas de disciplina graves o incompetencia y acorde a procedimientos justos que aseguren la objetividad e imparcialidad según la constitución o la ley. ${ }^{40}$

\footnotetext{
34 Corte Interamericana de Derechos Humanos caso "Reverón Trujillo vs. Venezuela" (2009): Sentencia de 30 de junio de 2009. Excepción Preliminar, Fondo, Reparaciones y Costas. Serie C No. 197, párrafo 67, citando caso "Herrera Ulloa vs. Costa Rica" (2004): Sentencia de 2 de julio de 2004. Excepciones Preliminares, Fondo, Reparaciones y Costas. Serie C No. 107, párrafo 171 y caso "Palamara Iribarne vs. Chile" (2005): Sentencia de 22 de noviembre de 2005. Fondo, Reparaciones y Costas, Serie C No. 135, párrafo 145.

35 Corte Interamericana de Derechos Humanos caso "Tribunal Constitucional vs. Perú" cit., párrafo 73 y caso "Atala Riffo y Niñas vs. Chile" (2012): Sentencia del 24 de febrero de 2012. Fondo, Reparaciones y Costas. Serie C, No. 239, párrafo 186.

${ }^{36}$ Corte Interamericana de Derechos Humanos caso "Apitz Barbera y otros ("Corte Primera de lo Contencioso Administrativo") vs. Venezuela." cit. y caso "Atala Riffo y Niñas vs. Chile” cit., párrafo 186.

37 Cfr. caso "Tribunal Constitucional vs. Perú" cit., párrafo 75, caso "Chocrón Chocrón vs. Venezuela” cit., párrafo 98, caso "Tribunal Constitucional (Camba Campos y Otros) vs. Ecuador" (2013): Sentencia de 28 de agosto de 2013, Excepciones Preliminares, Fondo, Reparaciones y Costas, párrafo 189. Ver también Principio 12 de los Principios Básicos de las Naciones Unidas.

38 Principio 11 de los Principios Básicos de las Naciones Unidas.

39 Principio 12 de los Principios Básicos de las Naciones Unidas.

40 Comité de Derechos Humanos, Observación General No. 32, Artículo 14: El Derecho a un Juicio Imparcial y a la Igualdad ante los Tribunales y Cortes de Justicia, CCPR/C/GC/32, 23 de agosto de 2007, párrafo 20. Además, en la misma Observación General el Comité ha expresado que "[l] destitución de jueces por el poder ejecutivo, por ejemplo antes de la expiración del mandato para el que fueron nombrados, sin que se les de ninguna razón concreta y sin que dispongan de una protección judicial efectiva para impugnar la destitución, es incompatible con la independencia del
} 
Fuentes - Principios internacionales que consagran el derecho humano de acceso a una justicia...

La Corte IDH ha acogido estos principios y ha afirmado que la autoridad a cargo del proceso de destitución de un juez debe conducirse independiente e imparcialmente en el procedimiento establecido para el efecto y permitir el ejercicio del derecho de defensa. ${ }^{41}$ Ello es así toda vez que la libre remoción de jueces fomenta la duda objetiva del observador sobre la posibilidad efectiva de aquellos de decidir controversias concretas sin temor a represalias. ${ }^{42}$

\section{IV.3. Garantías para evitar Presiones externas}

Existe una relación directa entre la dimensión objetiva de la independencia judicial y la dimensión subjetiva configurada por el derecho de los jueces a acceder y permanecer en sus cargos en condiciones generales de igualdad, como expresión de su garantía de estabilidad, lo cual fue puesto de resalto por la Corte IDH en el Caso del "Tribunal Constitucional (Camba Campos y Otros) vs. Ecuador". ${ }^{43}$

A ese respecto se estableció que los Principios Básicos disponen que los jueces resolverán los asuntos que conozcan "basándose en los hechos y en consonancia con el derecho, sin restricción alguna y sin influencias, alicientes, presiones, amenazas o intromisiones indebidas, sean directas o indirectas, de cualesquiera sectores o por cualquier motivo". ${ }^{44}$ Asimismo, dichos Principios establecen que "no se efectuarán intromisiones indebidas o injustificadas en el proceso judicial". ${ }^{45}$

El alcance de esta garantía radica en evitar que el sistema judicial en general y sus integrantes en particular, se vean sometidos a posibles restricciones indebidas en el ejercicio de su función por parte de órganos ajenos al Poder Judicial o incluso por parte de aquellos magistrados que ejercen funciones de revisión o apelación. ${ }^{46}$

En tal sentido, resulta sumamente ilustrativo lo señalado por el Juez Eduardo Ferrer Mac-Gregor Poisot en su voto en disidencia parcial a la

poder judicial" (párrafo 20). Asimismo, los Principios Básicos establecen que los jueces "sólo podrán ser suspendidos o separados de sus cargos por incapacidad o comportamiento que los inhabilite para seguir desempeñando sus funciones" y que "todo procedimiento para la adopción de medidas disciplinarias, la suspensión o la separación del cargo se resolverá de acuerdo con las normas establecidas de comportamiento judicial”. Principios 18 y 19 de los Principios Básicos de las Naciones Unidas.

${ }^{41}$ Cfr. caso "Tribunal Constitucional vs. Perú" cit., párrafo 74 y caso "Chocrón Chocrón vs. Venezuela” cit., párrafo 99.

42 Cfr. caso "Apitz Barbera y otros ("Corte Primera de lo Contencioso Administrativo") vs. Venezuela” cit., párrafo 44 y caso "Chocrón Chocrón vs. Venezuela” cit., párrafo 99. Ver también los principios 2, 3 y 4 de los Principios Básicos de las Naciones Unidas.

${ }^{43}$ Cfr. caso "Tribunal Constitucional (Camba Campos y Otros) vs. Ecuador" cit., párrafo 190.

44 Principio 2 de los Principios Básicos de las Naciones Unidas.

${ }^{45}$ Principio 4 de los Principios Básicos de las Naciones Unidas.

${ }^{46}$ Cfr. caso "Tribunal Constitucional vs. Perú”, cit., párrafo 75. 
sentencia dictada por la Corte IDH en el ya citado "Caso del Tribunal Constitucional (Camba Campos y Otros vs. Ecuador" ${ }^{47}$ en referencia a que: "La independencia judicial también se ha concebido a partir de su distinción como valor o como garantía. En cuanto a la independencia judicial como valor, su significado coincide con lo que se denomina 'independencia funcional' (también conocida como 'sustantiva' o 'decisional'). Esta concepción de la independencia judicial se traduce en la regla básica del ordenamiento según la cual el juez, en ejercicio de la función jurisdiccional, debe estar sometido únicamente a la legalidad, es decir, al vigente sistema de fuentes del derecho. Por otro lado, la independencia judicial como garantía, es un conjunto de mecanismos jurídicos tendientes a la salvaguarda y realización del valor mencionado, el cual es protegido mediante otros principios tales como la mencionada división de poderes, el juez natural, la imparcialidad, la exclusividad, etcétera . (...) Dentro de la concepción de la independencia judicial como garantía, pueden también distinguirse varias facetas. La primera de ellas es la llamada 'independencia personal' que es la que protege a cada juez en lo individual y que consiste en el conjunto de características de su estatus constitucional, que lo ponen al reparo de eventuales presiones de los órganos estatales de naturaleza política -el Parlamento y el Poder Ejecutivo-. Por otro lado, en tiempos más recientes, se identifica una independencia judicial de garantía en sus vertientes 'colectiva' e 'interna'. La independencia judicial colectiva tiende a proteger a la judicatura en su conjunto frente al resto de los poderes del Estado, mientras que la individual ampara al juez personalmente considerado incluso frente al resto de la estructura judicial".

De tal modo, es dable colegir que la protección institucional de la independencia judicial se relaciona directamente con el derecho del juez de permanecer en su cargo, como consecuencia de la protección de inamovilidad.

La Corte $\mathrm{IDH}^{48}$ ha señalado que el ejercicio autónomo de la función judicial debe ser garantizado por el Estado tanto en su faceta institucional, esto es, en relación con el Poder Judicial como sistema, así como también en conexión con su vertiente individual, es decir, con relación a la persona del juez específico. ${ }^{49}$

En tal sentido el tribunal interamericano estimó pertinente precisar que la dimensión objetiva se relaciona con aspectos esenciales para el Estado de Derecho, tales como el principio de separación de poderes y el importante rol que cumple la función judicial en una democracia. Por ello esta dimensión objetiva trasciende la figura del juez e impacta colectivamente en toda la sociedad. Asimismo existe una relación directa entre la dimensión objetiva de la independencia judicial y el derecho

\footnotetext{
47 Cfr. caso "Tribunal Constitucional (Camba Campos y Otros) vs. Ecuador" cit., voto en disidencia parcial Juez Eduardo Ferrer Mac-Gregor Poisot, párrafo 55-56.

${ }^{48}$ Cfr. caso "Tribunal Constitucional (Camba Campos y Otros) vs. Ecuador cit., párrafo 198

49 Cfr. caso "Apitz Barbera y otros ("Corte Primera de lo Contencioso Administrativo") vs. Venezuela”, cit., párrafo 55, y caso “Reverón Trujillo vs. Venezuela”, cit., párrafo 67.
} 
Fuentes - Principios internacionales que consagran el derecho humano de acceso a una justicia...

de los jueces a acceder y permanecer en sus cargos en condiciones generales de igualdad, como expresión de su garantía de estabilidad.

La CIDH a través de su documento "Garantías para la independencia de las y los operadores de justicia. Hacia el fortalecimiento del acceso a la justicia y el estado de derecho en las Américas" ${ }^{50}$ ha efectuado un firme alegato en defensa del sostenimiento de la independencia judicial, señalando que: "1. La vigencia de los derechos y libertades en un sistema democrático requiere un orden jurídico e institucional en el que las leyes prevalezcan sobre la voluntad de los gobernantes y los particulares, y en el que exista un efectivo control judicial de la constitucionalidad y legalidad de los actos del poder público. Con tal propósito, la Comisión Interamericana de Derechos Humanos ha resaltado el rol fundamental que desempeñan las y los operadores de justicia para hacer preservar el Estado de Derecho, posibilitando que toda denuncia pueda tomar su correcto cauce a través de los mecanismos jurisdiccionales dispuestos por el Estado, y en casos de violaciones a derechos humanos sea posible investigar, castigar efectivamente a los responsables y recibir una reparación, garantizando a su vez un debido proceso a toda persona que pueda ser sometida al ejercicio del poder punitivo del Estado. 2. Tal y como lo ha expresado la Relatora Especial de Naciones Unidas sobre la Situación de Defensores de Derechos Humanos, cuando las y los operadores de justicia contribuyen a que se logre el acceso efectivo a la justicia y realizan un esfuerzo especial en un proceso para que se imparta justicia de manera independiente e imparcial y garantizar así los derechos de las víctimas, puede decirse que actúan como defensores de los derechos humanos. Bajo dicha perspectiva, en el ámbito de la Comisión Interamericana, la Relatoría sobre Defensores y Defensoras de Derechos Humanos ha sido el punto focal encargado de realizar el seguimiento y monitoreo respecto de la situación de operadoras y operadores de justicia reconociendo que la función esencial que realizan para la defensa contribuye a que se logre el acceso efectivo a la justicia y realizan un esfuerzo especial en un proceso para que se imparta justicia de manera independiente e imparcial y garantizar así los derechos de las víctimas, puede decirse que actúan como defensores de los derechos humanos".

\section{Análisis de la Independencia Judicial en Argentina}

Expuestos los principios emergentes del derecho internacional sobre los que se sustenta el derecho humano que garantiza el efectivo goce de una justicia independiente, analizaremos el tema en la Argentina donde en los últimos años se produjeron reiterados episodios que afectaron su normal funcionamiento.

A tales fines formularemos un somero análisis evolutivo del contexto político en aquel país en la última década y el impacto que ello tuvo en la

\footnotetext{
50 Comisión Interamericana de Derechos Humanos "Garantías para la independencia de las y los operadores de justicia. Hacia el fortalecimiento del acceso a la justicia y el estado de derecho en las américas" Ob cit., p. 1. Disponible en http://www.cidh.org.
} 
independencia judicial; a lo cual incorporaremos distintas observaciones formuladas por organismos internacionales de derechos humanos y como ellos, junto con los principios internacionales antes enunciados, fueron receptados por la CSJN de ese país en los pronunciamientos más recientes sobre la materia en estudio.

Haremos especial énfasis en el último pronunciamiento de aquel tribunal argentino, en el cual se puso un punto final a los intentos del poder político de avanzar sobre la independencia del Poder Judicial. Dicho pronunciamiento recoge los postulados del derecho internacional sobre independencia judicial y tiene un valor de suma trascendencia para los países que conforman la Organización de Estados Americanos.

\section{V.1. Contexto político}

El desarrollo propuesto no puede ser efectuado sin hacerse una acotada mención de las circunstancias políticas ocurridas en la Argentina en la última década.

Luego de la grave crisis política y económica que atravesó este país hacia fines del año $2001,^{51}$ el lento proceso de reconstrucción de la institucionalidad implicó acudir a la "emergencia" para superar el estado de situación. Ello generó que a los fines de la reconstrucción tanto de la representación política como del tejido social gravemente afectado por la crisis económica, el poder presidencial se comenzara a ejercer exento de ciertos controles.

Para contextualizar la simiente de la problemática que intentaremos abordar es dable reseñar que el alongamiento de dicho contexto de emergencia hizo que los controles institucionales sobre el poder del Presidente fueran cada vez más laxos, lo que generó que la independencia y autonomía de los poderes del estado hayan experimentado un equilibrio cada vez más inestable.

Para entender este fenómeno quizás debamos analizar y poner en cuestión algunos aspectos de la historia política más reciente de la Argentina. El desarrollo efectuado por Guillermo O’Donell, en su trabajo "Democracia Delegativa" (O’Donell, 1994: 55-69) detalló cuestiones que, con el paso del tiempo, tuvieron significativa relevancia y tal vez sea hoy la crónica más acotada del ciclo político comprendido entre los años 2003-2015 en Argentina. En la exégesis de su pensamiento tomada de aquel trabajo se destaca que, en este particular ejercicio de la democracia, el Presidente es considerado como la encarnación del país, principal custodio e intérprete de sus intereses y una figura eminentemente paternalista. Su base política es un movimiento que se sitúa a sí mismo tanto sobre los partidos políticos, como sobre los intereses organizados. De acuerdo con esta visión, otras instituciones -por ejemplo la justicia y el poder legislativo- constituyen estorbos

\footnotetext{
${ }^{51}$ El 20 de diciembre del año 2001 el gobierno constitucional de Fernando De la Rúa llegó a su fin sumido en una grave crisis económica y política. Desde ese día y hasta el 2 de enero de 2002 se sucedieron cuatro presidentes.
} 
Fuentes - Principios internacionales que consagran el derecho humano de acceso a una justicia...

que acompañan a las ventajas a nivel nacional e internacional de ser un Presidente democráticamente elegido.

Esta modalidad consiste en establecer mediante elecciones limpias una mayoría que faculta a alguien para convertirse, durante un determinado número de años, en la encarnación y el intérprete de los altos intereses de la nación. La nación y su expresión política "auténtica", el líder y su "movimiento", se presentan como organismos vivos. El líder debe sanar a la nación mediante la unión de sus fragmentos dispersos en un todo armonioso que apela directamente a las masas.

Lo dicho hasta aquí resulta un dato de insoslayable ponderación para poner en tensión lo ocurrido en la Argentina desde el año 2003 donde, producto del contexto referido, progresivamente el poder del Presidente de la Nación fue engrosándose avanzando sobre la independencia de los otros poderes del Estado.

El afianzamiento de este hiperpresidencialismo (Nino, 1995: 569-653) ${ }^{52}$ tuvo dos fases: la primera en un contexto de emergencia económica y política en la que era necesario reconstruir las bases de la legitimación y la representación popular; y luego, en una segunda etapa, al amparo de la expresión de una amplia mayoría popular que legitimó su ejercicio y permitió profundizar la concentración de poder y la disminución de los controles.

\section{El avance sobre la independencia del Poder Judicial}

Como punto de inicio del presente acápite, en lo que constituye la centralidad de la problemática en análisis, debemos mencionar que el Consejo de la Magistratura es un órgano incorporado a la Constitución Argentina en la reforma del año 1994 con el objetivo de engrosar la independencia judicial y reducir la injerencia de la política en el procedimiento de selección de magistrados inferiores, especialmente en la etapa que se cumple ante el mismo.

$\mathrm{Al}$ respecto deviene necesario mencionar que en lo referente al proceso de nombramiento de magistrados "en diversas normas regionales, así como en varias observaciones finales del Comité de Derechos Humanos, se recomienda establecer una entidad independiente encargada de la selección de los jueces" (...) "la composición de este órgano reviste gran importancia para su independencia, pues sus integrantes deben seleccionar a los jueces de manera objetiva, justa e independiente". ${ }^{53}$

Por tal razón es que estas entidades -como lo es el Consejo de la Magistratura en Argentina- deben gozar de autonomía para establecer con claridad

\footnotetext{
52 Sobre el punto también se puede analizar un reciente trabajo de Hernández (2016).

${ }^{53}$ Informe del Relator Especial sobre la Independencia de los magistrados y abogados, Consejo de Derechos Humanos, A/HRC/11/41, 24 de marzo de 2009, párrafos 27-28. Disponible en http//www.ohchr.org./EN/Issues/Judiciary/Pages/Annual.aspx.
} 
el proceso de selección y el perfil del magistrado, garantizar la transparencia y publicidad durante todo el proceso, ya que solo mediante un procedimiento transparente y riguroso en relación con los méritos de los candidatos se puede asegurar la selección de los más aptos para conformar la judicatura. ${ }^{54}$

En su texto original, la Ley $24.937^{55}$ determinó que el Consejo de la Magistratura de Argentina estaría integrado por 20 consejeros: ocho legisladores (cuatro por la mayoría y cuatro por la primera y la segunda minoría), un representante del Ejecutivo Nacional, cinco jueces, cuatro abogados y dos académicos. Con esta composición la mayoría gobernante (de ser el mismo partido mayoría en el Congreso y el partido de la presidencia) tenía un cuarto de la representación, es decir, cinco miembros sobre veinte.

En el año 2006, en lo que fue presentado como un crítico contexto sobre la excesiva burocratización en el funcionamiento del Consejo de la Magistratura, se sancionó la Ley $26.080^{56}$ que introdujo significativas reformas a la ley orgánica que regula su funcionamiento, entre las que figura como dato sobresaliente, la reducción de veinte a trece de los miembros que lo integran, quedando conformado el Consejo por tres jueces, seis legisladores (cuatro por la mayoría y dos por la primera minoría), dos abogados, un representante del Ejecutivo Nacional y un académico o científico. De esta forma se redujo la representación de todos los sectores salvo la de la mayoría gobernante, que sigue contando con cinco miembros, pero en vez de ser sobre un total de veinte, ahora es sobre un total de trece, es decir casi el cuarenta por ciento de la conformación. Los representantes de jueces, abogados y académicos o científicos continuaban siendo seleccionados por sus pares.

En esta nueva composición, que intentaba dotar de mayor operatividad al cuerpo, no se observa la "equilibrada" integración que dispone el art. 114 de la Constitución Nacional y se otorga una excesiva participación a los órganos

\footnotetext{
${ }^{54} \mathrm{El}$ art. 114 de la Constitución Argentina edicta: "El Consejo de la Magistratura, regulado por una ley especial sancionada por la mayoría absoluta de la totalidad de los miembros de cada Cámara, tendrá a su cargo la selección de los magistrados y la administración del Poder Judicial. El Consejo será integrado periódicamente de modo que se procure el equilibrio entre la representación de los órganos políticos resultantes de la elección popular, de los jueces de todas las instancias y de los abogados de la matrícula federal. Será integrado, asimismo, por otras personas del ámbito académico y científico, en el número y la forma que indique la ley. Serán sus atribuciones: 1. Seleccionar mediante concursos públicos los postulantes a las magistraturas inferiores. 2. Emitir propuestas en ternas vinculantes, para el nombramiento de los magistrados de los tribunales inferiores. 3. Administrar los recursos y ejecutar el presupuesto que la ley asigne a la administración de justicia. 4. Ejercer facultades disciplinarias sobre magistrados. 5. Decidir la apertura del procedimiento de remoción de magistrados, en su caso ordenar la suspensión, y formular la acusación correspondiente. 6. Dictar los reglamentos relacionados con la organización judicial y todos aquellos que sean necesarios para asegurar la independencia de los jueces y la eficaz prestación de los servicios de justicia”.

55 Boletín Oficial de la República Argentina N² 28808, Buenos Aires del 06 de enero de 1998.

${ }^{56}$ Boletín Oficial de la República Argentina N 30854, Buenos Aires del 27 de febrero de 2006.
} 
Fuentes - Principios internacionales que consagran el derecho humano de acceso a una justicia...

políticos (Badeni, 2015) ${ }^{57}$ resultantes de la elección popular (siete en total), asegurándose el oficialismo gobernante cinco de esos consejeros.

Ello generó que para que ese cuerpo cumpla sus funciones más trascendentes, ello es aprobación de ternas y habilitación de proceso de remoción de magistrados, lo cual solo es posible con el voto de los dos tercios del total de los consejeros, necesariamente se deba contar con la anuencia de los representantes oficialistas. Más claramente, con esta composición se buscó detentar un poder de veto sobre las decisiones más trascendentales que debe cumplir el Consejo de la Magistratura. Al respecto vale aclarar que el término "equilibrio" -según la intención de los constituyentes- no significa que el número de representantes de cada estamento sean exactamente equivalentes, sino que en la composición de la institución no se permita a ningún estamento prevalecer sobre los demás.

Esta reforma fue objetada en el año 2010 por el Comité de Derechos Humanos de las Naciones Unidas, toda vez que en el marco de los informes presentados por los Estados Partes en virtud del artículo 40 del Pacto Internacional de Derechos Civiles y Políticos, Argentina informó que "Con respecto a la composición del Consejo de la Magistratura, explica que sólo 5 de un total de 13 miembros provienen del Gobierno, lo que descarta la posibilidad de una 'mayoría automática' o de influencia indebida del Gobierno en las deliberaciones del Consejo. Desde 2003, el Consejo nunca ha estado dirigido por el Ejecutivo, sino principalmente por representantes de los círculos académico o judicial totalmente independientes del poder ejecutivo, e incluso por personas que pertenecen claramente a la oposición política". ${ }^{58}$

A pesar del informe del Estado argentino, el Comité de Derechos Humanos observó con preocupación que: “.... pesar del principio contenido en el artículo 114 de la Constitución respecto al equilibrio que debe imperar en la composición del Consejo de la Magistratura, existe en el mismo una marcada representación de los órganos políticos allegados al Poder Ejecutivo, en detrimento de la representación de jueces y abogados (art. 2 del Pacto). El Estado parte debe tomar medidas con miras a hacer efectivo el equilibrio previsto en el precepto constitucional en la composición del Consejo de la Magistratura, evitando situaciones de control del Ejecutivo sobre este órgano". ${ }^{9}$

La delicada situación en la que se colocó la independencia judicial en Argentina, con la modificación del Consejo de la Magistratura, también fue

\footnotetext{
57 Con la Ley 26.080 se incrementó el desequilibrio. El estamento político cuenta con siete miembros (53,8\%), los jueces con tres (23\%), los abogados con dos $(15,3 \%)$, mientras que el sector científico y académico está representado por una persona.

58 ONU, Comité de Derechos Humanos, CCPR/C/SR.2691 - Acta de marzo 2010. Disponible en: http://goo.gl/H9t4Gy.

59 ONU. Comité de Derechos Humanos. $98^{\circ}$ período de sesiones. Nueva York, 8 a 26 de marzo de 2010, RG/CO/4.
} 
advertida por el Relator Especial sobre la Independencia de los Magistrados y Abogados de las Naciones Unidas" quien sostuvo "la clave del mandato constitucional sobre la integración del Consejo de la Magistratura es la de procurar el equilibrio y pluralidad de la representación", enfatizando en cuanto al cambio producido en su composición, que "(...)si bien el gobierno no tiene una mayoría propia para decidir por sí mismo, sí tiene en la práctica un poder de veto para impedir la decisión del Consejo en los asuntos más importantes a su tratamiento; este poder de veto, rompería claramente con el equilibrio de la representación plural fijado por la Constitución argentina, [ya que] en términos relativos y de peso en las decisiones, el Gobierno ha incrementado su poder y participación dentro del Consejo de la Magistratura".

El análisis de las cuestiones referentes a la reforma en la composición del Consejo de la Magistratura resulta de vital importancia, puesto que ello constituyó el punto de inflexión en la secuencia de velados embates a la independencia del Poder Judicial a lo que posteriormente se suma el fallido intento denominado de "democratización de la justicia" -según fue presentado por el Gobierno argentino-, mediante la sanción de la Ley $26.855 .^{61}$

Con dicha ley se proponía la siguiente integración del Consejo de la Magistratura: seis legisladores (cuatro por la mayoría y dos por la primera minoría), tres jueces (dos representantes de la lista que resulte ganadora por simple mayoría y un representante de la lista que resulte en segundo lugar), seis representantes del ámbito académico o científico (cuatro representantes de la lista que resulte ganadora y dos de la lista que resulte en segundo lugar), tres abogados (dos representantes de la lista que resulte ganadora y uno de la lista que resulte en segundo lugar) y un representante del Poder Ejecutivo. Además la ley establecía la elección popular de los representantes de los jueces, abogados y académicos a través de listas que conformarán los partidos políticos, modificando sustancialmente el sistema previsto por la Ley 24.937, conforme al cual los representantes de los jueces, abogados y de académicos son elegidos por sus respectivos pares.

La Ley 26.855 fue cuestionada por no respetar los estándares locales e internacionales sobre independencia judicial, puesto que se vulneraba el equilibrio dispuesto en la Constitución Nacional, ya que se estipulaba que la totalidad de los miembros del Consejo resultaran directa o indirectamente electos del sistema político-partidario, al proponer la elección de los representantes de los jueces, abogados y académicos a través del voto popular. De este modo, el proyecto soslayaba el principio de representación de los estamentos técnicos al establecer la

\footnotetext{
${ }^{60}$ Informe de la Relatora Especial sobre la Independencia de los Magistrados y Abogados. Consejo de Derechos Humanos, A/HRC/14/26/Add.1, 18 de junio de 2010, párrafos 3-4. En: http://www.ohchr.org/EN/Issues/Judiciary/Pages/Annual.aspx.

${ }^{61}$ Boletín Oficial de la República Argentina Nro. 32647, Buenos Aires del 27.05.2013.
} 
Fuentes - Principios internacionales que consagran el derecho humano de acceso a una justicia...

elección directa de jueces, abogados, académicos y científicos y comprometía la independencia judicial al obligar a los jueces a intervenir en la lucha partidaria.

Asimismo esa ley instauraba un peligroso cambio en el sistema vigente, puesto que se establecía la mayoría absoluta para la toma de las decisiones más relevantes con la finalidad declarada de agilizar el funcionamiento del cuerpo.

A tal punto fue el estrépito provocado por el proyecto de reforma en la composición del Consejo de la Magistratura ${ }^{62}$ que, la entonces Relatora Especial de las Naciones Unidas Gabriela Knaul, exhortó al Gobierno argentino a que reconsidere el proyecto de ley de reforma del Consejo de la Magistratura. La Relatora sostuvo que: "El Estado tiene el compromiso de asegurar la independencia de la judicatura mediante el respeto de su legislación a los estándares internacionales". ${ }^{63}$

Posteriormente, los artículos de la Ley 26.855 referidos a la integración popular de los miembros del Consejo de la Magistratura (artículos 2, 4, 18 y 30) fueron declarados inconstitucionales por la CSJN en el caso "Rizzo" la Corte sostuvo: "Que del sistema de selección de los miembros del Consejo de la Magistratura adoptado por esta ley 26.855 se sigue indefectiblemente que, con la modificación que ella introduce, doce (12) de los diecinueve (19) integrantes serán elegidos en forma directa por sufragio universal y los siete (7) restantes en forma indirecta por los órganos resultantes de la elección popular. De este modo, ya sea directa o indirectamente, la totalidad de los integrantes del Consejo tendría un origen político partidario". "Es claro, entonces, que esta modificación importa un evidente apartamiento de lo dispuesto en el artículo 114 de la Constitución Nacional que, ya se ha dicho, buscó asegurar una composición equilibrada entre los integrantes del Consejo, de modo tal que no tuvieran primacía los representantes provenientes del sistema de naturaleza exclusivamente político partidario respecto de los representantes del Poder Judicial, del ámbito profesional y del académico". ${ }^{65}$ La CSJN fundamentó su decisión en la inconstitucionalidad de: a) La elección popular de los representantes del estamento técnico; b) El incremento del número de representantes del sector académico o científico y c) La afectación de la independencia judicial al obligar a los jueces a intervenir en la

62 Ver Aponte (2013), en este trabajo el autor compila las críticas de diversos organismos, organizaciones y autores sobre la viabilidad del proyecto de reforma sustancial al Consejo de la Magistratura. Disponible en http://www.dplf.org/es/resources/un-intento-frustrado-en-argentinala-reforma-de-la-ley-del-consejo-de-la-magistratura-y-la.

63 ONU. Argentina / Reforma judicial: experta de la ONU pide garantias y respeto a la independencia del Poder Judicial. $30 / 04 / 2013$ http://www.ohchr.org/SP/NewsEvents/Pages/DisplayNews.aspx?NewsID=13275\&LangID=S ${ }^{64}$ Corte Suprema de Justicia de la Nación Argentina causa "Rizzo, Jorge Gabriel (apoderado Lista 3 Gente de Derecho) s/ acción de amparo c/ Poder Ejecutivo Nacional, Ley 26.855, medida cautelar". (2013): Sentencia del 18 de junio de 2013. Disponible en http://sjconsulta.csjn.gov.ar/sjconsulta/documentos/verDocumento.html?idAnalisis=702685\&int erno $=1$

${ }^{65}$ Corte Suprema de Justicia de la Nación Argentina causa “Rizzo, Jorge Gabriel” cit., párrafo 30. 
lucha partidaria. Asimismo, la CSJN dejó expresamente establecido que se mantenía la vigencia de la Ley 26.080 en cuanto a la composición del Consejo como respecto a las mayorías calificadas para adoptar sus decisiones.

Como bien lo señala un reciente informe realizado por la Asociación por los Derechos Civiles y Poder Ciudadano, ambas de Argentina, ${ }^{66}$ sin perjuicio de la declaración de inconstitucionalidad de la Ley 26.855, los problemas ocasionados por la citada Ley 26.080 en cuanto a la composición del órgano aún están vigentes, puesto que el oficialismo sigue detentando su poder de veto sobre las decisiones más importantes del Consejo de la Magistratura. Ello tiene incidencia directa en la problemática que desarrollaremos en los siguientes acápites.

Curiosamente, pese a la pretendida dinámica de funcionamiento que quiso brindarse al Consejo de la Magistratura, se produjo una llamativa parálisis en su funcionamiento, lo cual se tradujo en la mora en la realización de los concursos necesarios para cubrir las vacantes judiciales.

El Poder Ejecutivo ${ }^{67}$ a su vez, aplazó la remisión de las ternas de los candidatos al Senado y provocó que el número de vacancias en los distintos fueros aumentara a niveles sorprendentes. Según estimaciones efectuadas por la CSJN en noviembre de 2015, la cuarta parte del poder judicial funcionaba con jueces subrogantes. ${ }^{68}$ De tal modo que la excepcionalidad se transformó en regla y el servicio de justicia brindado al amparo de la legalidad constitucional fue puesto en serio riesgo.

\section{Inicio de las conflictivas designaciones de Jueces Subrogantes}

Producto del contexto antes referido de virtual paralización de los mecanismos para la designación de jueces y juezas, ahondaremos en lo subsiguiente sobre las cuestiones referidas a la indebida injerencia del poder político en la cobertura de esas vacancias y las inestimables consecuencias que ello acareó.

\footnotetext{
${ }^{66}$ Situación de la Independencia Judicial en Argentina (2015): Asociación por los Derechos Civiles y Poder Ciudadano. Disponible en www.adc.org.ar/.../informe-"La-situación-de-la-Independencia-Judicialen-Argentina.

${ }^{67}$ Según lo establece la Constitución Argentina, de acuerdo con el artículo 114 de la Constitución Nacional, el Consejo de la Magistratura tiene la función de "Seleccionar mediante concursos públicos los postulantes a las magistraturas inferiores". Asimismo, el artículo 99.4. dispone que el Presidente de la Nación "nombra los demás jueces de los tribunales federales inferiores en base a una propuesta vinculante en terna del Consejo de la Magistratura, con acuerdo del Senado, en sesión pública, en la que se tendrá en cuenta la idoneidad de los candidatos". Es decir, por mandato constitucional en el sistema de selección participan tres órganos: Consejo de la Magistratura, Poder Ejecutivo Nacional y Senado. Este procedimiento de selección se inicia con la realización del concurso público de oposición y antecedentes.

68 Sobre el punto ver el acabado análisis efectuado en "Situación de la Independencia Judicial en Argentina. Asociación por los Derechos Civiles y Poder Ciudadano”. Ob. cit.
} 
Fuentes - Principios internacionales que consagran el derecho humano de acceso a una justicia...

Al respecto no resulta baladí, como dato introductorio, aclarar que la subrogancia en un tribunal ocurre frente a la ausencia del titular, cualquiera sea el motivo (renuncia, licencia, excusación, recusación) y es una circunstancia transitoria, excepcional y debe ser -en principio- temporalmente restringida hasta que desaparezcan las razones que la motivaron o el tiempo que se le asignó.

En ese orden, se sancionaron las leyes $26.372^{69}$ y $26.376^{70}$ que estipulaban que las vacantes en principio tenían que ser cubiertas por otros jueces y, en su defecto, por sorteo entre los integrantes de una lista de conjueces elaborada por el Poder Ejecutivo con acuerdo del Senado.

La forma de cobertura de las vacancias en tribunales del fuero federal y de la justicia nacional, ha sido durante esta última década cuanto menos polémica y motivó que la CSJN, ya en el año 2007, declarara su inconstitucionalidad en el Fallo "Rosza", y dispusiera que debía cumplirse con los subrogantes, un procedimiento análogo al de los titulares, con la intervención de todos los órganos que contempla la Constitución precedido ello de un criterio de razonabilidad.

\section{VII.1 Evolución normativa y jurisprudencial}

A los fines de recordar los antecedentes que han dado origen a esta peligrosa modalidad de cobertura de subrogancias judiciales, vale remontarse a diciembre de 2003, cuando se sancionó la Ley $25.876^{72}$ que, en su artículo 1 , en lo que aquí importa, determinó lo siguiente:

Inclúyese como incisos del artículo 7 de la ley del Consejo de la Magistratura; inciso 15: Dictar los reglamentos que establezcan el procedimiento y los requisitos para la designación de jueces subrogantes en los casos de licencia o suspensión de su titular y transitorios en los casos de vacancia para los tribunales inferiores. El juez designado deberá cumplir con los requisitos previstos en el artículo 13 inciso b) primera parte de la presente ley, y percibirá una remuneración equivalente a la que correspondiera al titular.

En caso de vacancia las designaciones efectuadas en virtud del presente inciso no podrán superar el plazo de doce meses. Dicho plazo podrá ser prorrogado por seis meses por decisión fundada.

A consecuencia de la norma legal recién citada, el Consejo de la Magistratura dictó la Resolución 76/2004, aprobatoria del Reglamento de Subrogaciones de los Tribunales inferiores de la Nación, el que en su artículo 2 admitía la designación

\footnotetext{
${ }^{69}$ Boletín Oficial de la República Argentina No 31416, Buenos Aires 30 de mayo de 2008.

${ }^{70}$ Boletín Oficial de la República Argentina N 31420, Buenos Aires 05 de junio de 2008.

71 Corte Suprema de Justicia de la Nación Argentina causa "Rosza, Carlos Alberto y otros/ recurso de casación" (2007): sentencia de 23 de mayo de 2007, párrafo 14. Disponible en http://sjconsulta.csjn.gov.ar/sjconsulta/documentos/verUnicoDocumento.html?idAnalisis=628138 72 Boletín Oficial de la República Argentina N 30323, Buenos Aires 22 de enero de 2004.
} 
secretarios de ambas instancias para ocupar cargos de subrogantes de juzgados de primera instancia.

En cambio el artículo 4, referido al reemplazo en las Cámaras Federales con asiento en las provincias no menciona la subrogación como juez de cámara de los secretarios. Esta norma se aplicaba a los demás tribunales superiores según los artículos 6 y 7. En las subrogaciones prolongadas (mayores a 60 días) los Tribunales Superiores -Cámaras o Tribunales Orales- debían elevar una terna en la cual no se menciona que pudiera incluirse a los secretarios.

La modificación que introdujo en el artículo 2 del reglamento citado, la Resolución $\mathrm{N}^{\circ}$ 232/2004 del Consejo de la Magistratura incluyó entre los funcionarios que podían actuar como subrogantes de primera instancia a los prosecretarios de cámara. Y, en el artículo 4, incluyó a los secretarios de cámara no a los de primera instancia.

La Corte Suprema, inicialmente otorgó una suerte de aval provisorio a la aplicación del citado reglamento aprobado por Resolución 76/2004, fundándose en los trastornos que provocaría en la administración de justicia declarar la nulidad masiva de los actos producidos o que produjeran los subrogantes que proviniesen del rango de los secretarios, por medio de la acordada 7/2005 de la CSJN.

Posteriormente, el Congreso sancionó la Ley 26.080 por la que derogó el mencionado inc. 15 del art. 7 de la ley del Consejo de la Magistratura. Ello dio lugar a que el 28 de febrero de 2006 el Consejo de la Magistratura de la Nación dictase el Acta 4/06 por la que dispuso que hasta tanto el Congreso Nacional sancionara una ley reguladora de la materia, el Reglamento de Subrogaciones de los Tribunales Inferiores de la Nación mantendría plena vigencia.

Sin embargo, cuando la cuestión de constitucionalidad sobre la integración de los tribunales con secretarios llegó a la CSJN en forma de caso concreto, esta se pronunció por la inconstitucionalidad.

A ese respecto, el Máximo Tribunal concluyó que el régimen de subrogantes regulado mediante la Resolución 76/2004 del Consejo de la Magistratura -que establecía la posibilidad de subrogación por parte de los secretarios judiciales- no se adecuaba a los “(...)parámetros establecidos por la Constitución Nacional para la designación de magistrados judiciales, en particular, en cuanto autorizaba un método de nombramiento circunscripto a la intervención exclusiva de organismos que operaban en el ámbito del Poder Judicial (tribunales orales, cámaras nacionales de apelación y, para algunos supuestos, Comisión de Selección de Magistrados y Escuela Judicial de Consejo de la Magistratura). De ahí, que la no intervención de los Poderes en cuyas 
Fuentes - Principios internacionales que consagran el derecho humano de acceso a una justicia...

manos la Ley Suprema ha puesto la atribución para realizar aquellas designaciones tornaba al régimen en inconstitucional". ${ }^{73}$

No obstante, la declaración de inconstitucionalidad no se hizo valer para el pasado $^{74}$ y dio a los Poderes Ejecutivo y Legislativo el plazo de un año para establecer legalmente un régimen que se conformara a las pautas establecidas en el fallo previamente aludido.

Ese fallo de la CSJN fue seguido por sendas acordadas: la $\mathrm{N}^{\circ} 16$ del 17 de julio de 2007 y la $\mathrm{N}^{\circ} 22$ del 4 de septiembre del mismo año, según las cuales en el plazo dado para que se dicte la nueva ley de subrogaciones, estas debían efectuarse siempre con jueces titulares o jubilados o con abogados de la matrícula pertenecientes a la lista de conjueces.

A consecuencia de lo decidido en el precedente "Rosza", el Congreso Nacional dictó la Ley 26.376 la que, teniendo en cuenta la reforma posterior introducida por la Ley 26.855, estableció:

Artículo 1: En caso de recusación, excusación, licencia, vacancia u otro impedimento de los jueces de Primera Instancia Nacionales o Federales, la respectiva Cámara de la jurisdicción procederá a la designación de un subrogante de acuerdo al siguiente orden:

a) Con un juez de igual competencia de la misma jurisdicción, teniendo prelación el juez de la nominación inmediata siguiente en aquellos lugares donde tengan asiento más de un juzgado de igual competencia;

b) Por sorteo, entre la lista de conjueces confeccionada por el Poder Ejecutivo nacional, de acuerdo a lo dispuesto por el artículo 3 de la presente ley.

A su vez, el artículo 3 mencionado estableció que:

El Poder Ejecutivo nacional confeccionará cada tres (3) años una lista de conjueces, que contará con el acuerdo del Honorable Senado de la Nación. Los integrantes de la misma serán abogados de la matrícula federal que reúnan los requisitos exigidos por la normativa vigente para los cargos que deberán desempeñar.

\footnotetext{
${ }^{73}$ Corte Suprema de Justicia de la Nación Argentina causa "Rosza, Carlos Alberto y otros/ recurso de casación" cit. párrafos 14, 15 y 19 del voto de los jueces Lorenzetti, Highton de Nolasco y Maqueda, párrafos 20-21 del voto concurrente del juez Fayt.

${ }^{74}$ En cuanto al efecto que la Corte Suprema de Argentina determinó en el precedente "Rosza", siendo que allí se adoptó una decisión con efecto prospectivo, para un acabado y detenido análisis sobre este punto, puede consultarse Garay (2013).
} 
A esos efectos, se designaran entre diez (10) y treinta (30) conjueces por Cámara Nacional o Federal, según la necesidad de las respectivas jurisdicciones.

Conviene destacar que la CSJN, en el caso "Asociación de Magistrados y Funcionarios" 75 decidió que el art. 3 mencionado impide habilitar a los secretarios de ambas instancias para integrar las listas de conjueces que hayan de someterse a la aprobación del Senado. Y, también, declaró que esta limitación no afectaba la garantía de la igualdad. Reforzando de esta forma lo ya decidido en el precedente "Rosza".

En suma, tanto la Constitución Nacional como la normativa aplicable al caso, como los precedentes del Máximo Tribunal de la Nación resultaban uniformes en no habilitar a los Secretarios judiciales para el ejercicio de la función de Jueces Subrogantes.

\section{VII.2. Persistente inconvencionalidad e inconstitucionalidad del mecanismo para la designación de jueces subrogantes}

Sin perjuicio de lo dicho en el acápite anterior acerca de los precedentes del Máximo Tribunal, en junio del año 2015 se sancionó la nueva Ley $27.145^{76}$-que derogó las Leyes 26.372 y 26.376- aunque mantuvo el sistema de designación de jueces subrogantes por parte del Consejo de la Magistratura, según atribución de la Ley 26.855, siendo inclusive el nuevo régimen aún más gravoso que el previsto en las normas derogadas.

Sobre el particular, vale resaltar que el art. $2^{\circ}$ en sus párrafos $2^{\circ}, 3^{\circ}$ y $7^{\circ}$, de la Ley 27.145 contemplaba un mecanismo mediante el que, ante una vacante: a) el Consejo de la Magistratura como órgano de aplicación de la ley podía, sin ninguna clase de límite, elegir entre un juez, un conjuez abogado o un conjuez-secretario y b) si resolvía designar a un conjuez-abogado o a un conjuez-secretario, esto no se hacía mediante un mecanismo basado en baremos objetivos, sino que dependía la absoluta discrecionalidad del Consejo de la Magistratura.

El art. $3^{\circ}$, párr. $1^{\circ}$ permitía que el Plenario del Consejo de la Magistratura apruebe las listas de conjueces-abogados y conjueces-secretarios con mayoría simple.

El art. $4^{\circ}$ disponía que para el supuesto excepcional que no hubiere disponible una lista de conjueces con acuerdo del Senado para cubrir una vacante producida, el Consejo de la Magistratura designaría subrogantes de la lista

\footnotetext{
75 Corte Suprema de Justicia de la Nación Argentina causa "Asociación de Magistrados y Funcionarios c/ EN -ley 26372 artículo 2 s/ amparo ley 16986.” (2012): Sentencia de 4 de diciembre $\quad 2012.2$ De 2 Disponible http://sjconsulta.csjn.gov.ar/sjconsulta/documentos/verDocumento.html?idAnalisis=695722\&int erno $=1$.

${ }^{76}$ Boletín Oficial de la República Argentina N³3153, Buenos Aires del 18 de junio de 2015.
} 
Fuentes - Principios internacionales que consagran el derecho humano de acceso a una justicia...

aprobada por el Plenario. Estas designaciones tendrán un plazo máximo de duración de noventa (90) días hábiles, prorrogable por única vez por igual término. $\mathrm{El}$ art. 10 permitía a su vez designar a conjueces abogados de una lista propuesta por el Poder Ejecutivo con acuerdo del Senado, pero sin aprobación del Consejo de la Magistratura.

Por último, en lo que resulta un dato de extrema irrazonabilidad, el art. $1^{\circ}$ -último párrafo- disponía que en el caso de tribunales respecto de los cuales hubiera transcurrido el plazo previsto por la ley de creación para su puesta en funcionamiento, se contara con el crédito presupuestario necesario para la habilitación y se encontrara en trámite el concurso para cubrir la vacante, el Consejo de la Magistratura podía designar un juez subrogante y hacer efectivo su inmediato funcionamiento.

\section{VII.2.1. Análisis de la Ley 27.145}

En efecto, el art. $2^{\circ}$ de dicha ley estableció, que:

El Consejo de la Magistratura designará subrogantes por mayoría absoluta de los miembros presentes. La designación se realizará con un juez o jueza de igual competencia de la misma jurisdicción o con un miembro de la lista de conjueces confeccionada de acuerdo a lo dispuesto en el art. $3^{\circ}$ de la presente ley.

El precepto transcripto contenía dos inconstitucionalidades flagrantes, las que fueron acogidas en la contundente sentencia de la CSJN, sobre las que ahondaremos en los acápites siguientes.

Asimismo, resultaba inconstitucional -según ya lo había determinado la CSJN- el art. 7 del Reglamento para Subrogaciones de los Tribunales Inferiores de la Nación dictado por el Consejo de la Magistratura (Res. No 8/2014 según atribución reconocida por la Ley 26.855), en cuanto allí se contemplaba la posibilidad de designar a los Secretarios Judiciales como Jueces Subrogantes.

\section{VII.2.1.1. Irrazonable modificación del régimen de mayorías y el rol del Consejo de la Magistratura en el procedimiento de designación de magistrados}

En primer lugar, el art. 2 de la Ley 27.145 resultaba inconstitucional por cuanto modificaba el régimen de mayorías que se requiere para aprobar los concursos de designación de jueces y remitir al Poder Ejecutivo la terna vinculante.

Así es que, con la entrada en vigencia de dicha ley, se disponía que "el Consejo de la Magistratura designará subrogantes por mayoría absoluta de los miembros presentes". Dicho dispositivo resultaba claramente contrario a los precedentes aplicables a la cuestión de las subrogancias judiciales, ya que la 
CSJN, en el considerando 14 en "Rosza", 77 había precisado que el procedimiento de nombramiento de jueces subrogantes inexorablemente debe cumplir con los mismos requisitos institucionales que el nombramiento de los jueces titulares en cada una de las instancias correspondientes y estar precedido de un criterio de "razonabilidad".

En tal sentido, a fin de garantizar la independencia de los jueces, la Corte Suprema en el precedente aludido entendió que corresponde que las mayorías requeridas al plenario del Consejo, en cuanto a los jueces subrogantes, sean idénticas que para los jueces titulares. Es decir, cumplir la exigencia de contar con el aval de, al menos, $2 / 3$ de los miembros del Plenario del Consejo de la Magistratura.

A mayor abundamiento, si lo dispuesto en el art. 2 de la ley se analiza en conjunto con otras estipulaciones que establecían que la lista de subrogantes podía ser conformada sin que los candidatos sean sometidos a un correcto análisis de idoneidad (art. 3) y que en algunos casos hasta se podrá prescindir de la participación del Poder Ejecutivo Nacional y/o del Senado de la Nación -siendo el Consejo de la Magistratura quien directamente designe y ponga en funciones al subrogante (art. 4)-, se evidencia la enorme peligrosidad que la utilización de ese mecanismo irradiaba sobre la independencia e imparcialidad del Poder Judicial.

De tal modo es dable colegir que el Consejo de la Magistratura, según lo estipulaba el régimen de la Ley 27.145, dejaba de actuar sus competencias propias, siendo que no resultaba necesario transitar las instancias evaluadoras que la manda constitucional le asigna en el art. 114 para designar a los jueces subrogantes.

Frente a dicho contexto, se generó una suerte de jurisdicción paralela con jueces que fueron puestos en su cargo a partir de un procedimiento que se sustentaba en una ajustada mayoría simple de consejeros de la magistratura.

Este sistema previsto en la Ley 27.145, que reedita el mecanismo de la 26.376, desnaturaliza la función para la cual fue creado el Consejo de la Magistratura, violándose los superiores principios de la Constitución Nacional y lo resuelto por la CSJN en el precedente "Rizzo". ${ }^{78}$

Así, según los criterios del Constituyente del año 1994, recogidos por la CSJN en "Rizzo" “...sin un Poder Judicial independiente e idóneo resulta imposible controlar los actos de gobierno y garantizar los derechos de los habitantes. Las reformas propuestas en el despacho que defendemos tienden a otorgarle independencia e idoneidad al Poder Judicial. Ello se consigue a través de

\footnotetext{
${ }^{77}$ Corte Suprema de Justicia de la Nación Argentina causa "Rosza, Carlos Alberto y otros/ recurso de casación".

78 Corte Suprema de Justicia de la Nación Argentina causa "Rizzo, Jorge Gabriel (apoderado Lista 3 Gente de Derecho) s/ acción de amparo c/ Poder Ejecutivo Nacional, Ley 26.855, medida cautelar” cit.
} 
Fuentes - Principios internacionales que consagran el derecho humano de acceso a una justicia...

la creación de un Consejo de la Magistratura..." (...) “...queremos ser bien precisos en los objetivos que esta reforma persigue y en el sentido de las cláusulas que estamos reformando, de modo tal de constituir una fuente clara de interpretación [...] Toda norma que pueda implicar alguna limitación a la independencia del Poder Judicial, a la independencia e imparcialidad de la composición del Consejo de la Magistratura (...) debe considerarse que vulnera el espíritu de la Constitución y contradice la intención del constituyente. (...) no puede quedar duda alguna de que las propuestas que estamos analizando tienden a construir la base de una nueva y más amplia democracia, al crearse nuevas instituciones que aseguren un mejor equilibrio entre los poderes y desconcentren las facultades presidenciales" (Alfonsín, 1994).

Vale rememorar que, como ya hemos ahondado al respecto, el objetivo buscado al incorporar el art. 114 de la Constitución Nacional fue reducir la injerencia de la política en el procedimiento de selección de magistrados inferiores, especialmente en la etapa que se cumple ante el Consejo de la Magistratura.

\section{VII.2.1.2. Desaparición de la preferencia a favor de magistrados para la cobertura de subrogancias}

En segundo lugar, el art. 2 de la Ley 27.145 resultaba inconstitucional, como lo juzgó el Máximo Tribunal, en tanto modificaba el régimen anterior previsto en la Leyes 26.372 y 26.376 , las que preveían que en el caso de subrogancias, en primer lugar, las vacantes debían de ser cubiertas por otros jueces y, en su defecto, por sorteo entre los integrantes de una lista de conjueces, elaborada por el Poder Ejecutivo Nacional con acuerdo del Senado de la Nación.

Con la sanción de esta nueva ley se modificó dicha prelación, estableciéndose que el Consejo de la Magistratura podía designar a su arbitrio entre un juez de igual competencia y de la misma jurisdicción o un miembro de una lista de conjueces elaborada por el propio Consejo con acuerdo del Senado.

Ello acarreaba que la designación de subrogantes podía recaer indistintamente (sin orden de prevalencia ni necesidad de justificación) en un magistrado de igual competencia y jurisdicción (que cuenta con las garantías de independencia e imparcialidad propias de su calidad) o bien, en un conjuez elegido discrecionalmente y sin sorteo, pudiendo ser escogidos estos abogados sin experiencia judicial y carentes de aquellas garantías.

La norma habilitaba que la mayoría simple del Consejo de la Magistratura pueda optar discrecionalmente en cubrir una vacante con un juez de la Constitución de igual competencia o elegir libremente a un integrante de la lista de conjueces, sin expresar las razones que justifiquen el motivo de dicha elección entre una y otra alternativa. Lo expuesto denota la inocultable irrazonabilidad legislativa que presentaba el sistema. 
Ello es así en tanto que ante una situación de vacancia, por los motivos que fuere, la cobertura más apropiada a la Jurisprudencia y a la legalidad constitucional lógicamente debe ser la que recae en un juez titular, que cumplió con todos los procedimientos legales para acceder al cargo y provisto de las garantías de independencia e imparcialidad que le asigna el art. 110 de la Constitución Nacional. ${ }^{79}$

Vale recordar que la integración de los abogados al sistema de subrogaciones fue concebida para situaciones excepcionales puntualmente delimitadas y, en todos los casos, en pos de la resolución de una causa específica en caso de excusación, recusación o impedimento alguno del juez natural.

Ahora bien, hacer extensivo dicho principio de manera general implica permitir que un abogado de la matrícula -incluso funcionarios del Poder Ejecutivo Nacional matriculado según lo preveía el art. 6 de la Ley 27.145- podía subrogar un juzgado y ejercer, en idénticas condiciones que los jueces titulares, las demás funciones que recaen sobre los magistrados, lo cual constituye un dato carente de toda lógica.

La Ley 27.145 eliminaba la razonable prelación para la designación de un juez subrogante: 1) en primer lugar, debería recaer la función en cabeza de un magistrado de igual competencia, de la misma jurisdicción de ser posible; 2) como segunda opción, el régimen de la Ley 26.376 establecía que de resultar imposible designar a un magistrado, se proceda a un sorteo de una lista de conjueces. En cambio, esta nueva ley eliminó la exigencia de un sorteo, dejando librada la designación de un juez subrogante a la mera discrecionalidad de una simple mayoría absoluta de miembros presentes del Consejo de la Magistratura.

En razón de ello, resulta absurdo en términos constitucionales que se haya habilitado al Consejo de la Magistratura para que, indistintamente, optara por un juez o miembro de la lista de conjueces por sobre los jueces de la constitución.

Desde luego que por la trascendencia que acarrea el debido proceso y la figura del "juez natural" estas premisas resultaban inadmisibles en pos de la defensa del estado de derecho. Lo expuesto implicaba una grosera irregularidad en el proceso de selección para la designación de un juez, habiéndose instaurado de esta forma un sistema que permitía la conformación de comisiones especiales de juzgamiento expresamente prohibidas por la Constitución Nacional en su art. 18.

A un mayor abundamiento, si colegimos que los concursos deben garantizar la mayor idoneidad entre los postulantes, no existe razón para que un juez subrogante no cumpla con tales parámetros, esa era la solución prevista por la

\footnotetext{
79 Artículo 110.- Los jueces de la Corte Suprema y de los tribunales inferiores de la Nación conservarán sus empleos mientras dure su buena conducta, y recibirán por sus servicios una compensación que determinará la ley, y que no podrá ser disminuida en manera alguna, mientras permaneciesen en sus funciones.
} 
Fuentes - Principios internacionales que consagran el derecho humano de acceso a una justicia...

Ley 26.376 y que la CSJN avaló en el precedente "Aparicio"80 donde el Máximo Tribunal entendió que "la situación de los abogados conjueces no guarda analogía con la de los presidentes de las cámaras federales que, de acuerdo a las disposiciones del art. 22 del decreto ley 1285/1958 -texto según ley 14.467 y sus modificatorias-, pueden ser convocados para integrar la Corte Suprema de Justicia de la Nación. Ello es así pues estos magistrados, a diferencia de los abogados que integran la lista de conjueces, cuentan al momento de asumir su función provisoria con una designación ajustada a los procedimientos que, conforme a la Constitución Nacional, los habilitan a administrar justicia en forma independiente e imparcial, asegurando las garantías constitucionales y convencionales de los justiciables (confr. art. 99, inc. $4^{\circ}$, segundo párrafo), y el legislador les asignó esa función atendiendo a esa condición preexistente".

El otorgamiento de funciones judiciales en personas que no son jueces solo debería estar reservado para casos de extrema necesidad constitucional, es decir, cuando no exista absolutamente ninguna posibilidad de designar para el cargo o para la causa a un juez que cumpla el estándar de razonabilidad constitucional.

\section{VII.2.1.3. Magistrados sin estabilidad}

De la exégesis de la Ley 27.145, surge que los magistrados subrogantes no gozaban de estabilidad, ello en franca inobservancia de lo estipulado en la Constitución Argentina ${ }^{81}$ y en los principios internacionales que antes desarrollamos.

En tal sentido, como lo ha sostenido la Corte IDH, la estabilidad, como las otras garantías de las que deben gozar las y los jueces, deben ser ofrecidas por el Estado tanto a jueces titulares como provisorios. ${ }^{82}$

Asimismo, la omisión resultaba aún más evidente en razón que la reforma judicial de 2013 (Ley 26.855) dispuso que los jueces provisorios debían removerse por juicio político.

\footnotetext{
${ }^{80}$ Corte Suprema de Justicia de la Nación Argentina causa "Aparicio, Ana Beatriz y otros e/ EN CSJN- Consejo de la Magistratura - art. 110 s/ empleo público.” (2015): sentencia de 21 de abril de 2015. Disponible

http://sjconsulta.csjn.gov.ar/sjconsulta/documentos/verDocumento.html?idAnalisis=720915\&int erno $=1$

81 Artículo 115: Los jueces de los tribunales inferiores de la Nación serán removidos por las causales expresadas en el Artículo 53, por un jurado de enjuiciamiento integrado por legisladores, magistrados y abogados de la matrícula federal. Su fallo, que será irrecurrible, no tendrá más efecto que destituir al acusado. Pero la parte condenada quedará no obstante sujeta a acusación, juicio y castigo conforme a las leyes ante los tribunales ordinarios. Corresponderá archivar las actuaciones y, en su caso, reponer al juez suspendido, si transcurrieren ciento ochenta días contados desde la decisión de abrir el procedimiento de remoción, sin que haya sido dictado el fallo. En la ley especial a que se refiere el Artículo 114, se determinará la integración y procedimiento de este jurado.

82 Corte Interamericana de Derechos Humanos Caso "Chocrón Chocrón vs. Venezuela", cit., párrafo 103.
} 
La Ley 27.145, como ya fue puesto de manifiesto en los acápites precedentes, habilitaba al Consejo de la Magistratura a designar y remover jueces subrogantes a discreción con tan solo la mayoría simple de sus miembros.

En definitiva, el nuevo sistema de designación de jueces provisorios establecido por la Ley 27.145, sumado a la falta de estabilidad de los subrogantes actuales, autorizaba al que el Consejo de la Magistratura pueda remover a los últimos y reemplazarlos por magistrados afines a sus intereses.

Un caso emblemático de la vigencia de esta ley fue el del juez Luis María Cabral, quien ejercía funciones como subrogante en la Sala I de la Cámara Federal de Casación Penal desde 2011. Dicha sala debía decidir en un caso que era sensible al Poder Ejecutivo. Se trataba del caso donde se discutía la constitucionalidad del memorándum de entendimiento celebrado entre Argentina e Irán, con el fin de esclarecer el atentado a la Asociación Mutual Israelita Argentina (AMIA). El 25 de junio de 2015, Cabral fue removido por el Consejo de la Magistratura y se designó en su lugar a un funcionario del gobierno nacional. Para ello se aplicó la nueva Ley $27.145{ }^{83}$ Este es un buen ejemplo de las complejas situaciones que se han generado por un uso arbitrario e ilegal de un sistema de subrogancias endeble y contradictorio. ${ }^{84}$

La ausencia de estabilidad supone un riesgo para la independencia judicial. Como ha sostenido la CIDH "la ausencia de garantías de estabilidad para un operador de justicia conlleva el riesgo de que tome sus decisiones sólo con el objeto de complacer a la autoridad de la cual depende la renovación de su nombramiento o permanencia en el cargo". 85

Para la Corte IDH, la independencia judicial no debe estar garantizada solamente en la Constitución local, sino que -como ya lo reseñamos- todo el ordenamiento de administración de justicia en su conjunto debe garantizar la independencia judicial. ${ }^{86}$ Por lo tanto las normas inferiores, como la Ley 27.145, deben asegurar la estabilidad en el cargo. De lo contrario, vulnerarían el principio de independencia judicial consagrado en el artículo 8.1 de la Convención Americana de Derechos Humanos.

\section{Desnaturalización de las misiones del Consejo de la Magistratura}

Con lo expuesto en los puntos anteriores, se concluye que la Ley 27.145 importó una norma inconstitucional e inconvencional, en tanto confirió al Consejo de la

\footnotetext{
${ }^{83}$ Consejo de la Magistratura de la Nación. Resolución 180/2015.

${ }^{84}$ Situación de la Independencia Judicial en Argentina. Asociación por los Derechos Civiles y Poder Ciudadano. Ob. cit., p. 35.

85 Comisión Interamericana de Derechos Humanos. Garantías para la independencia de las y los operadores de justicia. Ob. cit. Párrafo 90.

${ }^{86}$ Corte Interamericana de Derechos Humanos. Caso “Anzualdo Castro vs. Perú” cit., párrafo 90.
} 
Fuentes - Principios internacionales que consagran el derecho humano de acceso a una justicia...

Magistratura una competencia de la que carece, convirtiéndolo en un órgano de designación de magistrados.

En el procedimiento de designación de magistrados, la función que debe desarrollar el Consejo de la Magistratura debe ceñirse, por imperio constitucional, a la elaboración de una terna vinculante, previo concurso público de antecedentes y oposición.

El constituyente le ha atribuido la función de selección y no la de designación, puesto que ello importa un acto complejo que excede la labor propia del Consejo, en tanto requiere de la necesaria intervención de otros poderes y órganos públicos.

Como hemos reflejado, la ley no discriminaba entre "selección" y "propuesta", por un lado, con "designación" por el otro. Aquellas atribuciones, sí corresponden al Consejo de la Magistratura, aunque la última resulta impropia y de imposible atribución por la voluntad del legislador ordinario.

A tal punto era el absurdo, que la Ley 27.145 permitía que el Consejo de la Magistratura designe unilateralmente un juez subrogante con una mayoría absoluta, aunque para aprobar una terna es necesario contar con dos tercios de los votos de la totalidad de los Consejeros.

Tal contrasentido obedecía a la intención de eludir el esquema constitucional de designación de magistrados, optando por un mecanismo cuyo deliberado fin era colonizar el Poder Judicial con jueces subrogantes dependientes del oficialismo de turno.

Así, se configuró la gravísima situación de que coexistan, en paralelo, dos categorías de jueces: unos, ajustados al mandato constitucional en tanto resultan dotados de las garantías previstas por la norma suprema a fin de apuntalar su independencia; y otros que -desprovistos de tales resortes institucionales- eran jueces a todas luces inconstitucionales, lo cual indudablemente generó una situación más gravosa e ilegítima aún que la existente antes de que la CSJN se pronunciara en "Rosza".

Todo ello acarreó una grave afectación al normal servicio de justicia, puesto que el Poder Judicial, en condición de poder contramayoritario, debe conservar las garantías suficientes para mantener la equidistancia de los otros poderes del Estado. Por esa razón, a fin de salvaguardar su legitimidad, resulta necesario que quienes accedan a la magistratura lo hagan por los canales institucionales reglados, a fin de garantir la idoneidad e independencia que por imperativo constitucional resultan intrínsecas a la función judicial. 


\section{El caso "Uriarte". Su trascendencia republicana}

El sistema de designación de jueces subrogantes como fue relatado, desde sus inicios, resultó un tema sumamente álgido.

El día 4 de noviembre de 2015, la CSJN emitió un trascendental pronunciamiento $^{87}$ que puso fin al peligroso mecanismo utilizado por el Poder Ejecutivo Nacional para designar jueces subrogantes, no solo desconociendo los precedentes de aquel máximo tribunal al respecto, sino eludiendo los dispositivos emergentes de la legalidad constitucional y supranacional.

La importancia del precedente y la rapidez con la que se resolvió la cuestión, denotan la enorme importancia que el tema presentaba. Ello es así, puesto que desde la sanción de la Ley 27.145 se generó un estado de enorme incertidumbre en torno a la independencia, imparcialidad e inamovilidad de ciertos magistrados judiciales que habían sido designados para cubrir, como subrogantes, las vacancias en distintos tribunales de la justicia federal y nacional. Dicho contexto generó múltiples denuncias de inconstitucionalidad sobre aquel cuerpo normativo.

\section{IX.1. Cuestiones fácticas}

La modalidad de cobertura de subrogancias judiciales antes particularizada, fue la aplicada por el Consejo de la Magistratura en diciembre del año $2014^{88}$ para proveer la designación del juez subrogante que cubrió la vacancia de Juzgado Federal $N^{\circ} 1$ de la ciudad de La Plata. Resultaba objetable dicha subrogancia -según los precedentes de la CSJN sobre el particular- por el hecho que la misma se había dispuesto con la designación de un secretario de cámara.

Dicho juzgado, es importante mencionar, tiene competencia electoral para controlar la legalidad de todo el proceso eleccionario, ya sea en la Primaria Abierta Simultánea y Obligatoria, como en la elección general, en toda la Provincia de Buenos Aires que representa casi el 40\% del padrón electoral nacional.

\footnotetext{
87 Corte Suprema de Justicia de la Nación Argentina causa "Uriarte Rodolfo Marcelo y otro c/Consejo de la Magistratura de la Nación s/acción mere declarativa de incontitucionalidad" (2015): Sentencia de 4 de noviembre de 2015. Disponible en http://sjconsulta.csjn.gov.ar/sjconsulta/documentos/verDocumento.html?idAnalisis=726287\&int erno $=2$

${ }^{88}$ La cobertura de la vacancia del Juzgado Federal $N^{\circ} 1$ de La Plata fue provista por el Consejo de la Magistratura de la Nación el día 18 de diciembre de 2014 por Resolución 331/14, en cumplimiento del artículo $7^{\circ}$ del "Reglamento de Subrogaciones de los Tribunales Inferiores de la Nación", aprobado por la Resolución 8/14 del Consejo de la Magistratura. En ese entonces se encontraban vigentes las Leyes 26.372 y 26.376, aunque al momento de fallar la CSJN la validez del acto de designación del juez subrogante de aquel trascendental Juzgado, dicha designación se había provisto conforme las estipulaciones de la nueva Ley 27.145 sancionada luego de promovida la acción de inconstitucionalidad. Al respecto ver fallo "Uriarte", párrafos 5-6.
} 
Fuentes - Principios internacionales que consagran el derecho humano de acceso a una justicia...

Frente a dicha circunstancia y en consonancia al dudoso marco normativo aludido, dirigentes del centenario partido político Unión Cívica Radical demandaron, mediante una acción declarativa de certeza, la inconstitucionalidad de la normativa legal y reglamentaria por la cual el Consejo de la Magistratura de la Nación determinó la subrogancia para el Juzgado con competencia electoral para toda la Provincia de Buenos Aires, ante la razonable incertidumbre de encontrarnos en vísperas de un proceso electoral sin juez natural designado por el mecanismo constitucional.

\section{IX.2. Breve sumario de lo acontecido en las instancias ordinarias}

En los autos "Uriarte, Rodolfo Marcelo y otro c/Consejo de la Magistratura de la Nación s/acción mere declarativa de inconstitucionalidad" que tramitaron ante el Juzgado Federal $\mathrm{N}^{\circ} 4$ de La Plata, se dictó sentencia de grado que declaró inconstitucional el régimen de subrogancias previsto en la Ley 27.145, dejando sin efecto la designación dispuesta para cubrir la vacante del Juzgado Federal $\mathrm{N}^{\circ} 1$, ordenando al Consejo de la Magistratura de la Nación que, hasta tanto sea cubierta la vacante en forma definitiva, provea la designación de juez subrogante en dicho juzgado de acuerdo a la legalidad constitucional. El pronunciamiento judicial fue proyectado para ser de cumplimiento inmediato, aunque la Sala I de la Excma. Cámara Federal de La Plata entendió que existía un supuesto de gravedad institucional y otorgó efecto suspensivo al pronunciamiento hasta tanto se expida sobre la apelación interpuesta por el Estado Nacional.

El fallo dictado por el juez a cargo del Juzgado Federal $\mathrm{N}^{\circ} 4$, constituyó un resguardo a la garantía de independencia del poder judicial y su lectura ${ }^{89}$ invita a la reflexión, no ya sobre el caso particular, sino acerca de la perniciosa realidad de pretender jueces militantes y consustanciados con la necesidades del poder político de turno.

Posteriormente el Tribunal de Alzada interviniente revocó el fallo de primera instancia en cuanto entendió que la Ley 27145 regló definitivamente lo resuelto por la CSJN en el fallo "Rosza" y concluyó, que esta nueva ley es superadora del bagaje normativo anterior, pues permite al Consejo de la Magistratura decidir quién resulta ser el más idóneo para cubrir una subrogancia entre un juez de igual competencia o un integrante de la lista de conjueces.

Así la Alzada arribó a la conclusión final respecto que, si bien en el procedimiento de subrogación no intervinieron el Poder Ejecutivo -elección de uno de los candidatos de la terna- ni el Poder Legislativo -acuerdo del Senado-, el Consejo de la Magistratura está integrado con representación de los órganos políticos resultantes de la elección popular, de los jueces de todas las instancias y

$89 \quad$ Disponible en http://scw.pjn.gov.ar/scw/viewer.seam?id=71ZZX1B7SCOIpJiz58bu4smd85GC1Vcfm\%2BR0m wKF8QE\%3D\&tipoDoc=despacho\&cid $=384964$. 
los abogados de la matrícula federal (Art. 114 C.N.) de forma tal que se procura un esquema participativo entre los poderes democráticos, estamentos vinculados con la actividad forense y por los propios jueces.

\section{IX.3. El fallo de la Corte Suprema de Justicia}

El fallo en análisis constituye, sin lugar a dudas, uno de los más valiosos precedentes de la jurisprudencia argentina de los últimos tiempos y sienta las bases para la observancia de la independencia judicial, armonizando las normas domesticas a los principios emergentes del derecho internacional. La importancia que el mismo presenta, ha de merecer un riguroso y pormenorizado análisis.

El día 4 de noviembre de 2015 la CSJN por unanimidad, ante la apelación interpuesta por la actora, declaró la inconstitucionalidad la de la Resolución 331/14 del Consejo de la Magistratura de la Nación, del artículo $7^{\circ}$ del "Reglamento de Subrogaciones de los Tribunales Inferiores de la Nación", aprobado por la Resolución 8/14 del Consejo de la Magistratura, del Decreto 1264/2015 y del régimen de subrogaciones establecido por la Ley 27.145. En el mismo sentido, se declaró la nulidad del acto de designación del Juez Subrogante del Juzgado Federal $\mathrm{N}^{\circ} 1$ de La Plata y se resolvió la invalidez del nombramiento de todos aquellos jueces que se encuentren subrogando y cuyo procedimiento de designación no se haya ajustado a las pautas fijadas en dicha sentencia.

En los considerandos de dicha sentencia, la CSJN entendió que los principios constitucionales y supranacionales que rigen para la designación de los magistrados, a los afectos de preservar la garantía del juez natural y el derecho de toda persona a ser oída por un tribunal competente, independiente e imparcial, tienen como objeto evitar que el sistema judicial en general y sus integrantes en particular se vean sometidos a posibles restricciones indebidas en el ejercicio de sus funciones por parte de órganos ajenos al Poder Judicial. Por ende, es un deber insoslayable del Estado garantizar una apariencia de independencia de la magistratura que inspire legitimidad y confianza suficiente al justiciable y al resto de las personas que conviven en una sociedad democrática. ${ }^{90}$

En el cumplimiento de dichos preceptos esenciales que aseguren la recta prestación del servicio de justicia mediante jueces independientes, resulta imperioso que ellos cuenten con garantías reforzadas que son indispensables para el ejercicio de su función. Entre ellas, en lo que a este caso interesa, se encuentran la de un adecuado proceso de nombramiento y la inamovilidad en el cargo. En ese orden, el máximo tribunal sentenció que los procedimientos constitucionales que regulan la integración de los tribunales han sido inspirados en móviles superiores de elevada política institucional, con el objeto de impedir el predominio de intereses subalternos sobre el interés supremo de la justicia y de la ley. Las disposiciones que rigen esos procedimientos se sustentan pues, en la aspiración de

\footnotetext{
${ }^{90}$ Corte Suprema de Justicia de la Nación Argentina causa "Uriarte” cit., párrafos 7-9.
} 
Fuentes - Principios internacionales que consagran el derecho humano de acceso a una justicia...

contar con una magistratura independiente e imparcial, lo que está directamente relacionado con la consagración constitucional de la garantía del "juez natural", expresada en la contundente prohibición de que los habitantes de la Nación puedan ser juzgados por comisiones especiales o sacados de los jueces legítimamente nombrados (artículo 18 de la Constitución Nacional). ${ }^{91}$

En cuanto al tema puntual de los jueces subrogantes, el Máximo Tribunal consideró que los principios antes expuestos no excluyen la implementación de un régimen de jueces subrogantes para actuar en el supuesto de producirse una vacante y hasta tanto esta sea cubierta de conformidad con el sistema constitucional, a los efectos de no afectar el derecho de las personas de contar con un tribunal que atienda en tiempo oportuno sus reclamos.

Sin embargo, enfatizó -conforme lo había ya expresado en "Rosza" en el año 2007- que los subrogantes desempeñan las mismas funciones que los jueces titulares, esto es, administrar justicia. En consecuencia, los justiciables tienen el derecho que surge de la Constitución Nacional y de los tratados internacionales. Para ello citó los precedentes de la Corte Interamericana de Derechos Humanos ${ }^{92}$ en el sentido que, "...los jueces que resuelvan sus controversias, aunque provisorios, sean y aparenten ser independientes...". De ese modo al efectuar el control de convencionalidad la CSJN invocó la jurisprudencia de la Corte IDH, mediante la cual se considera que la provisionalidad no debe significar alteración alguna del régimen de garantías para el buen desempeño del juzgador y la salvaguarda de los propios justiciables. De aquí se sigue que, aunque los jueces titulares y los subrogantes son designados de manera diferente y tienen un grado distinto de estabilidad, el Estado debe garantizar un procedimiento para el nombramiento de estos últimos sobre la base de parámetros básicos de objetividad y razonabilidad que aseguren el ejercicio independiente de su cargo. ${ }^{93}$

En ese orden, ahondó la $\mathrm{CSJN}^{94}$ en que la implementación de un régimen de subrogaciones es un remedio excepcional de política judicial que, ante supuestos de ausencia transitoria o permanente del juez titular de un determinado tribunal, persigue mantener el normal funcionamiento de la administración de justicia mediante el reemplazo de dicho magistrado, sea para una causa en particular -recusación o excusación-o para todas aquellas que se encuentren en trámite y que se inicien con posterioridad -vacancia, licencia, suspensión o cualquier otro impedimento-, utilizando nuevamente la jurisprudencia de la Corte $\mathrm{IDH}^{95}$ la cual ha sostenido que "los nombramientos provisionales deben constituir una situación de excepción y no la regla, ya que la extensión en el tiempo de la

\footnotetext{
${ }^{91}$ Corte Suprema de Justicia de la Nación Argentina causa "Uriarte" cit., párrafo 10.

92 “Apitz Barbera y otros." cit., párrafo 43; caso "Reverón Trujillo vs. Venezuela” cit., párrafo 114 y caso "Chocrón Chocrón vs. Venezuela" cit., párrafo 103.

${ }^{3}$ Corte Suprema de Justicia de la Nación Argentina causa "Uriarte" cit., párrafo 11.

${ }^{94}$ Corte Suprema de Justicia de la Nación Argentina causa "Uriarte" cit., párrafo 12.

95 Corte Interamericana de Derechos Humanos caso "Apitz Barbera" cit., párrafo 43 y caso

"Reverón Trujillo" cit., párrafo 118.
} 
provisionalidad de los jueces o el hecho de que la mayoría de ellos se encuentren en dicha situación, generan importantes obstáculos para la independencia judicial" y agregó dicho Tribunal Interamericano que a los efectos de que "el Poder Judicial cumpla con la función de garantizar la mayor idoneidad de sus integrantes, los nombramientos en provisionalidad no pueden prolongarse de manera indefinida, de tal forma que se conviertan en nombramientos permanentes. Ello es una nueva razón que explica que la provisionalidad sea admisible como excepción y no como regla general y que deba tener una duración limitada en el tiempo, en orden a ser compatible con el derecho de acceso a las funciones públicas en condiciones de igualdad". "En esa misma línea argumental la CSJN sostuvo que, por el contrario, los integrantes de las listas de conjueces carecen de designación permanente alguna, por lo que resultan más vulnerables a las presiones de diferentes sectores principalmente de aquellas autoridades de quienes dependen futuras designaciones $\mathrm{o}$ ascensos y "es menos probable que denuncien la conducta indebida o los actos de corrupción que presencien" (conf. Informe del Relator Especial sobre la independencia de los magistrados y abogados, A/67/305, 13 de agosto de 2012). ${ }^{97}$

$\mathrm{Al}$ calor de estos fundamentos la CSJN declaró la inconstitucionalidad del régimen de subrogancias establecido por la Ley 27.145 y reafirmó los parámetros constitucionales y supranacionales que se deben instar para proveer el mecanismo de designación de jueces subrogantes para cubrir las vacantes transitorias o permanentes que se produzcan.

De tal modo, la sentencia comentada determinó que las vacantes siempre deben ser cubiertas por magistrados de otros tribunales que fueron designados mediante los procedimientos previstos por la Constitución y, solo de manera excepcional y frente a razones objetivas que impidan designar a jueces, se puede recurrir a jueces provisionales provenientes de una lista de conjueces. ${ }^{98}$

El sistema de designación de los subrogantes, según el fallo en análisis, debe estar basado en baremos objetivos que puedan justificar para cada designación la preferencia de un candidato respecto de los restantes, toda vez que el sistema impugnado permite que el Consejo de la Magistratura ejerza con absoluta discrecionalidad su atribución de designar jueces subrogantes pudiendo elegir directamente entre aquellos comprendidos en el artículo $2^{\circ}$ de la Ley 27.145, qué persona quiere para un juzgado o tribunal determinado y también para una causa en particular. Para ello la Corte Suprema sostuvo que los Principios Básicos Relativos a la independencia de la judicatura expuesto por las Naciones Unidas disponen, en su punto 10, que todo método utilizado para la selección de personal judicial garantizará que este no sea nombrado por motivos indebidos. En tal sentido, cito las conclusiones del relator especial de Naciones Unidas sobre la independencia de los magistrados y abogados, quien recomendó que los Estados

\footnotetext{
${ }^{96}$ Caso "Reverón Trujillo” cit., párrafo 118 y caso “Chocrón Chocrón” cit., párrafo 107.

${ }^{97}$ Corte Suprema de Justicia de la Nación Argentina causa "Uriarte" cit., párrafo 17.

${ }^{98}$ Corte Suprema de Justicia de la Nación Argentina causa "Uriarte" cit., párrafo 18.
} 
Fuentes - Principios internacionales que consagran el derecho humano de acceso a una justicia...

establecieran mecanismos objetivos tales como el sorteo o la distribución automática siguiendo un orden alfabético con el objeto de evitar manipulaciones en la asignación de casos. ${ }^{99}$

En cuanto a la aprobación de la lista de conjueces por parte del Consejo de la Magistratura, debe responder a una mayoría agravada de dos tercios que es la que fija el art. 13, apartado C, de la Ley 24.937 para aprobar las ternas de candidatos a jueces permanentes. En esta materia, el Máximo Tribunal de Justicia de Argentina destacó la importancia de las mayorías calificadas ha sido destacada por la Corte IDH quien ha señalado -en las "Garantías para la independencia de las y los operadores de justicia. Hacia el fortalecimiento del acceso a la justicia y el estado de derecho en las Américas", Informe de la Comisión Interamericana de Derechos Humanos, OEA/Ser.L/V/ II, Doc. 44, del 5/12/2013, pto. 93- que ellas constituyen una salvaguardia para reforzar los procedimientos de selección de magistrados, pues evitan las mayorías partidarias e incrementan la transparencia, resultando más evidente para el público que se elige a los candidatos con base al mérito y las capacidades personales. En consecuencia, concluyó el máximo tribunal, la disposición examinada soslaya el importante rol que cumplen las mayorías calificadas en la búsqueda de equilibrios y consensos en los órganos colegiados y colisiona con la intención del constituyente de 1994 que, al definir la composición del Consejo de la Magistratura, procuró evitar que en el seno de ese cuerpo pudieran consolidarse posiciones hegemónicas (confr. "Rizzo", en especial considerando 25). ${ }^{100}$

Por ello es que la Corte Suprema reiteró la doctrina del precedente "Rosza" y determinó que los conjueces integrantes de esas listas deben ser nombrados mediante un procedimiento complejo donde participen el Consejo de la Magistratura, el Poder Ejecutivo y el Senado de la Nación. ${ }^{101}$

En cuanto al último párrafo del art. 1 de la Ley 27.145, la CSJN sostuvo que no se pueden realizar designaciones de jueces subrogantes respecto de tribunales que todavía no se encuentran en funcionamiento porque no hay juez a quien sustituir, ni causas en trámite, ni posibilidad de que se asigne el conocimiento de las que se iniciaren en el futuro. ${ }^{102}$

Sentados los puntos antes extractados, el máximo tribunal se vio nuevamente obligado a destacar la significativa cantidad de designaciones provisorias existentes en el ámbito del Poder Judicial de la Nación. Esta situación, que ya fuera señalada en el año 2007 al decidir la causa "Rosza", se ha agravado con el trascurso de los años, siendo que al momento de dictarse el fallo, aproximadamente un cuarto de los cargos de los tribunales nacionales y federales

\footnotetext{
${ }^{99}$ Corte Suprema de Justicia de la Nación Argentina causa "Uriarte" cit., párrafos 20-21.

100 Corte Suprema de Justicia de la Nación Argentina causa "Uriarte" cit., párrafo 24.

101 Corte Suprema de Justicia de la Nación Argentina causa "Uriarte" cit., párrafo 25.

102 Corte Suprema de Justicia de la Nación Argentina causa "Uriarte” cit., párrafos 26-29.
} 
se encontraban vacantes en forma permanente. Esta realidad, según lo reflejó el tribunal, devino imputable en gran medida a la demora en los procesos de selección y designación de magistrados a cargo del Consejo de la Magistratura, del Senado y del Poder Ejecutivo de la Nación, y pone de manifiesto que el carácter extraordinario del sistema de reemplazos se encuentra claramente desvirtuado, convirtiéndose en regla la excepción. Más claramente determinó "[h]oy la regla es designar un subrogante y la excepción es nombrar a un juez mediante un concurso". Además, atento a las mencionadas demoras que se verifican en los concursos para cubrir en forma definitiva las vacantes, estos jueces subrogantes pueden perdurar por un plazo indefinido en esos cargos, desnaturalizándose la esencia y la razón de ser de la figura del subrogante. De este modo, los propios órganos a los que la Constitución Nacional les asigna la función de designar jueces no solo no han cubierto en tiempo y forma el importante porcentaje de cargos vacantes sino que, además, han dictado normas por las que se habilitaron a designar jueces al margen del procedimiento constitucional creando una justicia de excepción en la que no rige la garantía del juez natural ni de independencia judicial. ${ }^{103}$

\section{Consideraciones finales}

Como hemos reflejado a lo largo del presente trabajo, la independencia del poder judicial resulta de vital importancia, no solo para el sostenimiento del equilibrio y separación de poderes, sino para garantizar el efectivo goce y reconocimiento de los derechos y garantías consagrados en las instituciones domésticas y en los distintos instrumentos internacionales.

Por tal motivo es que los principios aquí desarrollados con tanto ahínco se posan en la necesidad de contar con una justicia capaz de resolver las contiendas frustratorias de derechos de la forma más imparcial e independiente posible.

Ello no se logrará sin antes transitar un cuidadoso proceso que arroje transparencia y objetividad en la selección de los jueces y juezas que serán los garantes del cumplimiento de las máximas del debido proceso. Por ello, una vez sorteado el proceso de acreditación de idoneidad y cumplidos los pasos del mecanismo complejo de designación, es de vital trascendencia que quienes desempeñen la magistratura lo hagan a resguardo de elementales garantías como lo es la inamovilidad de sus cargos, lo cual permite conservar la necesaria equidistancia de los otros poderes constituidos.

Podemos colegir que en países donde la figura del Presidente se ha visto exacerbada y proyectada por sobre las instituciones, ello impactó directamente sobre el Poder Judicial enervando su independencia.

103 Corte Suprema de Justicia de la Nación Argentina causa "Uriarte” cit., párrafos 31-32. 
Fuentes - Principios internacionales que consagran el derecho humano de acceso a una justicia...

A tal punto ello ha sido así, que en el caso de Argentina la penetración de la ideología política de la fuerza gobernante hizo que se conforme una línea de magistrados judiciales identificados directa y abiertamente con el gobierno, autodenominados "justicia legítima". Hechos de estas características son los que han generado un enorme estado de incertidumbre en torno al normal servicio de justicia en aquel país.

Un claro ejemplo que refleja de manera elocuente lo que ocurre en Argentina con la justicia en torno a la politización -en todos sus niveles e instancias- de quienes tienen la delicada misión de impartir justicia, es la del actual Juez de la Corte IDH Raúl Zaffaroni, quien luego de renunciar a la CSJN, fue propuesto por el gobierno argentino ante la Organización de Estados Americanos para ocupar dicho cargo.

Lo concreto es que sobre Zaffaroni pesan innumerables impugnaciones en razón de que, contemporáneamente a su designación como juez de la Corte IDH, ha desarrollado una intensa actividad político-partidaria, descalificando los procesos políticos que actualmente se desarrollan en la Argentina y Brasil, al considerarlos "golpes institucionales". Asimismo Zaffaroni ha actuado en forma ostensible como asesor legal de la ex presidenta Cristina Kirchner en las causas penales que afronta, habiendo inclusive emitido opiniones críticas sobre otros procesos en los que se investiga la presunta comisión de delitos por parte de exfuncionarios y dirigentes y ha cuestionado las actuaciones que se labran en el combate a la corrupción en nuestro país y denostado a los jueces actuantes en declaraciones y actos públicos partidarios. Es decir que el achaque que fundan estas denuncias es que al mismo tiempo que desempeña un cargo de juez en un tribunal internacional, Zaffaroni se dedica a la actividad política, a la militancia partidaria, a inmiscuirse en los asuntos judiciales y de política interna de nuestro país y de Brasil, asesorando profesionalmente a imputados de delitos de corrupción o de graves inconductas en el ejercicio de sus funciones, a punto tal que ello generó que el Colegio Público de Abogados de la Capital Federal Argentina lo haya suspendido en su matrícula. Lo reflejado sobre este actual miembro de la Corte IDH constituye el epígono de la justicia Argentina de la última década.

En el sendero final de este corolario y como aporte concreto para la observancia de la máxima republicana de independencia judicial, vale remarcar que los distintos códigos de ética para los jueces (como ser los de Paraguay y Venezuela, el Código Iberoamericano de Ética Judicial y el Código de Conducta de para los Jueces Federales de Estados Unidos) concluyen en una idea absolutamente clara e irreductible y es que la politización de los miembros del Poder Judicial lastima la imagen de imparcialidad e independencia que deben proyectar siempre los jueces. El costo de formar parte de la magistratura incluye el de no poder hacer comentarios políticos de ninguna naturaleza, porque ellos son incompatibles con la función de juzgar que corresponde a los sistemas democráticos. 
Los jueces no solo deben ser independientes, sino que también deben parecerlo. Es un deber insoslayable del Estado garantizar una apariencia de independencia de la magistratura que inspire legitimidad y confianza suficiente al justiciable y al resto de las personas que conviven en una sociedad democrática. 
Fuentes - Principios internacionales que consagran el derecho humano de acceso a una justicia...

\section{BIBLIOGRAFÍA}

* Alfonsín, Raúl R. (1994): "Núcleo de Coincidencias Básicas” Editorial La Ley, Buenos Aires. Tomo D, pp. 824.

* ApOnTE Núñez, Emercio José (2013): Un intento frustrado en Argentina. La reforma de la ley del Consejo de la Magistratura y la independencia judicial. Fundación para el Debido Proceso Legal (DPLF).

* Asamblea General de Naciones unidas (2007): Comité de Derechos Humanos, Observación General No. 32, Artículo 14: El Derecho a un Juicio Imparcial y a la Igualdad ante los Tribunales y Cortes de Justicia, CCPR/C/GC/32, 23 de agosto de 2007.

(2009): Consejo de Derechos Humanos. Informe del Relator Especial sobre la independencia de los magistrados y abogados, Leandro Despouy, A/HRC/11/41, 24 de marzo de 2009.

(2008): Promoción y Protección de todos los Derechos Humanos, Civiles, Políticos,

Económicos, Sociales y Culturales, incluido el Derecho al Desarrollo. Informe del Relator Especial sobre la independencia de los magistrados y abogados, Leandro Despouy, A/HRC/8/4, 13 de mayo de 2008.

* Asociación por los Derechos Civiles y Poder Ciudadano (2015): Situación de la Independencia Judicial en Argentina, Argentina.

* Badeni, Gregorio (2016): "La reorganización del Consejo de la Magistratura", Tomo A, Editorial La Ley, Buenos Aires.

* Comisión Interamericana de Derechos Humanos (2003): Informe sobre la situación de derechos bumanos en Venezuela, OEA/Ser.L/V/II.118, Doc. 4 rev. 1., 24 de octubre de 2003. (2013): Garantías para la independencia de las y los operadores de justicia. Hacia el fortalecimiento del acceso a la justicia y el estado de derecho en las américas, OEA/Ser.L/V/II. Doc. 44.5 diciembre 2013. Original: Español.

* Comisión Internacional de JuRistas (2007): Principios Internacionales sobre Independencia y Responsabilidad de Jueces, Abogados y Fiscales, Guía para profesionales ( $\mathrm{N}^{\circ}$ 1), Editorial Comisión Internacional de Juristas, Ginebra.

* Corte Interamericana de Derechos Humanos (1990): Opinión Consultiva oc-11/90 del 10 de agosto de 1990 "Excepciones al agotamiento de los recursos internos" (arts. 46.1, 46.2.a y 46.2.b, Convención Americana sobre Derechos Humanos).

* (1986): Opinión Consultiva “La expresión 'leyes' en el artículo 30 de la Convención Americana sobre Derechos Humanos", 9 de mayo de 1986, 0C-6/86, Serie A No. 6.

* DíAZ, Elías (1998): Estado de derecho y sociedad democrática, Editorial Taurus, Madrid.

* Donini, Massimo (2004): "Jueces y democracia. El papel de la magistratura y democracia penal; el uso judicial del derecho penal de los principios", en Revista de Estudios de la Justicia. Santiago.

* Garay, Alberto (2013): La doctrina del Precedente en la Corte Suprema, Editorial Abeledo Perrot, Buenos Aires.

* HitTers, Juan Carlos (2015): "Control de convencionalidad (adelantos y retrocesos)", en Revista Iberoamericana de Derecho Procesal Constitucional, N²2, Julio-Diciembre de 2014, Editorial Porrúa. México.

* Hamilton, Alexander, Madison, James y Jay, John (1957): El Federalista, Edición del Fondo de Cultura Económica, México.

* Hernández, Antonio M. (2016): "Reformas constitucionales y los sistemas de gobiernos presidenciales", en Diario La Ley, Argentina, 19 de febrero de 2016.

* informe de la Relatora Especial sobre la independencia de los Magistrados y Abogados (2010): Consejo de Derechos Humanos, A/HRC/14/26/Add.1, 18 de junio de 2010.

* Informe de Relator Especial sobre independencia de jueces y abogados (1995): Documento de la ONU E/ CN.4/1995/39. 
* informe del Relator especial sobre la independencia de los magistrados y Abogados (2009): Consejo de Derechos Humanos, A/HRC/11/41, 24 de marzo de 2009.

* Naciones Unidas (2005): Consejo Económico y Social. Comisión de Derechos Humanos. Informe presentado por Leandro Despouy, Relator Especial sobre la independencia de los magistrados y abogados. Adición. Misión a Brasil. E/CN.4/2005/60/Add.3, 22 de febrero de 2005.

* (1985): Principios Básicos de las Naciones Unidas relativos a la independencia de la judicatura adoptados por el Séptimo Congreso de las Naciones Unidas sobre Prevención del Delito y Tratamiento del Delincuente, Milán, Italia, del 26 de agosto al 6 de septiembre de 1985, y confirmados por la Asamblea General en sus resoluciones 40/32 del 29 de noviembre de 1985 y 40/146 del 13 de diciembre de 1985.

* Nino, Carlos Santiago (1992): Fundamentos de Derecho Constitucional. Análisis filosófico, jurídico y politológico de la práctica constitucional, Editorial Astrea, Buenos Aires.

* O’Donell, Guillermo (1994): Democracia Delegativa, Publicado originalmente como "Delegative Democracy", Journal of Democracy, Vol. 5, ( $\mathrm{N}^{\circ}$. 1), National Endowment for Democracy and The Johns Hopkins University Press.

\section{JURISPRUDENCIA}

* Corte Europea de Derechos Humanos “Case of Galstyan v. Armenia” (2007): 15 Noviembre 2007.

* Corte Interamericana de Derechos Humanos "Caso Almonacid Arellano y otros Vs. Chile" (2006): Sentencia de 26 de septiembre de 2006. (Excepciones Preliminares, Fondo, Reparaciones y Costas). Serie C No. 154.

* Corte Interamericana de Derechos Humanos "Caso Anzualdo Castro Vs. Perú" (2009): Sentencia de 22 de Septiembre de 2009. (Excepción Preliminar, Fondo, Reparaciones y Costas). Serie C No. 202.

* Corte Interamericana de Derechos Humanos "Caso Apitz Barbera y otros ("Corte Primera de lo Contencioso Administrativo") Vs. Venezuela” (2008): Sentencia de 5 de agosto de 2008. (Excepción Preliminar, Fondo, Reparaciones y Costas). Serie C No. 182.

* Corte Interamericana de Derechos Humanos "Caso Atala Riffo y Niñas Vs. Chile" (2012): Sentencia del 24 de febrero de 2012. (Fondo, Reparaciones y Costas). Serie C No. 239.

* Corte Interamericana de Derechos Humanos "Caso Barbani Duarte y Otros Vs. Uruguay" (2011): sentencia del 13 de octubre de 2011. (Fondo Reparaciones y costas). Serie C No. 243.

* Corte Interamericana de Derechos Humanos "Caso Boyce y otros vs. Barbados" (2007): sentencia del 20 de noviembre de 2007. (Excepción Preliminar, Fondo, Reparaciones y Costas). Serie C No. 169.

* Corte Interamericana de Derechos Humanos "Caso Chocrón Chocrón Vs. Venezuela" (2011): Sentencia de 1 de julio de 2011. (Excepción Preliminar, Fondo, Reparaciones y Costas). Serie C No. 22.

* Corte Interamericana de derechos Humanos "Caso Corte Suprema de Justicia (Quintana Coello y otros) vs. Ecuador” (2013): 23 de agosto de 2013. (Excepción Preliminar, Fondo, Reparaciones y Costas). Serie C No. 266.

- Corte Interamericana de Derechos Humanos "Caso Duque vs. Colombia” (2016): sentencia de 26 de febrero de 2016. (Excepciones Preliminares, Fondo, Reparaciones y Costas). Serie C No. 310.

* Corte Interamericana de Derechos Humanos, "Caso Genie Lacayo v. Nicaragua" (1997): Sentencia de 29 de enero de 1997. (Fondo, Reparaciones y Costas). Serie C No. 30.

* Corte Interamericana de Derechos Humanos "Caso Godínez Cruz c. Honduras" (1989): sentencia de 20 de enero de 1989. (Fondo) ). Serie C No. 5. 
Fuentes - Principios internacionales que consagran el derecho humano de acceso a una justicia...

* Corte Interamericana de Derechos "Caso Herrera Ulloa Vs. Costa Rica" (2004): Sentencia de 2 de julio de 2004. (Excepciones Preliminares, Fondo, Reparaciones y Costas). Serie C No. 107.

* Corte Interamericana de Derechos Humanos "Caso La Cantuta vs. Perú" (2006): sentencia del 29 de noviembre de 2006. (Fondo, Reparaciones y Costas). Serie C No. 162.

* Corte Interamericana de Derechos Humanos, "Caso Myrna Mack Chang Vs. Guatemala" (2003): Sentencia de 25 de noviembre de 2003. (Fondo, Reparaciones y Costas). Serie C No. 101.

* Corte Interamericana de Derechos Humanos "Caso Palamara Iribarne Vs. Chile" (2005): Sentencia de 22 de noviembre de 2005. (Fondo, Reparaciones y Costas). Serie C No. 135.

* Corte Interamericana de Derechos Humanos "Caso Raxcacó Reyes vs. Guatemala" (2008): Resolución del 9 de mayo de 2008. (Supervisión de Cumplimiento de Sentencia).

* Corte Interamericana de Derechos Humanos "Caso Reverón Trujillo Vs. Venezuela" (2009): Sentencia de 30 de junio de 2009. (Excepción Preliminar, Fondo, Reparaciones y Costas). Serie C No. 197.

* Corte Interamericana de Derechos Humanos "Caso Trabajadores Cesados del Congreso (Aguado Alfaro y otros) Vs. Perú" (2006): Sentencia de 24 de noviembre de 2006. (Excepciones Preliminares, Fondo, Reparaciones y Costas). Serie C No. 158.

* Corte Interamericana de Derechos Humanos "Caso del Tribunal Constitucional Vs. Perú" (2001): sentencia de 31 de enero de 2001. (Fondo, Reparaciones y Costas). Serie C No. 71.

* Corte Interamericana de Derechos Humanos "Caso del Tribunal Constitucional (Camba Campos y Otros) vs. Ecuador" (2013): Sentencia de 28 de agosto de 2013. (Excepciones Preliminares, Fondo, Reparaciones y Costas). Serie C No. 268.

* Corte Interamericana de Derechos Humanos "Caso Velásquez Rodríguez c. Honduras" (1988): de 29 de julio de 1988. (Fondo). Serie C No. 4.

* Corte Interamericana de Derechos Humanos "Caso Yatama Vs. Nicaragua" (2005): Sentencia de 23 de junio de 2005. (Excepciones Preliminares, Fondo, Reparaciones y Costas). Serie C No. 127.

* Corte Suprema de Justicia de la Nación Argentina causa "Aparicio, Ana Beatriz y otros e/ EN -CSJN- Consejo de la Magistratura - art. $110 \mathrm{~s} /$ empleo público.” (2015): sentencia de 21 de abril de 2015.

* Corte Suprema de Justicia de la Nación Argentina causa "Asociación de Magistrados y Funcionarios c/ EN -ley 26372 artículo 2 s/ amparo ley 16986.” (2012): Sentencia de 4 de diciembre de 2012.

* Corte Suprema de Justicia de la Nación Argentina causa "Rizzo, Jorge Gabriel (apoderado Lista 3 Gente de Derecho) s/ acción de amparo c/ Poder Ejecutivo Nacional, ley 26.855, medida cautelar". (2013): Sentencia del 18 de junio de 2013.

* Corte Suprema de Justicia de la Nación Argentina causa "Rosza, Carlos Alberto y otros/ recurso de casación" (2007): sentencia de 23 de mayo de 2007.

* Corte Suprema de Justicia de la Nación Argentina causa "Uriarte Rodolfo Marcelo y otro c/Consejo de la Magistratura de la Nación s/acción mere declarativa de incontitucionalidad" (2015): Sentencia de 4 de noviembre de 2015. 